\title{
PRÁTICAS, CONSUMOS E RISCOS DIGITAIS DOS JOVENS ESTUDANTES ANGOLANOS
}

\section{RELATÓRIO DO INQUÉRITO UAL/ISCED 2020}

Investigadores:

Bruno Carriço Reis (UAL), Carlos Pedro Dias (UAL), Hélder Bahu (ISCED), João Carlos Sousa (UAL), Paula Lopes (UAL) e Vítor Tomé (UAL).

\section{Coordenadores:}

Hélder Bahu (ISCED)

Bruno Reis e Paula Lopes (UAL/NIP-C@M).
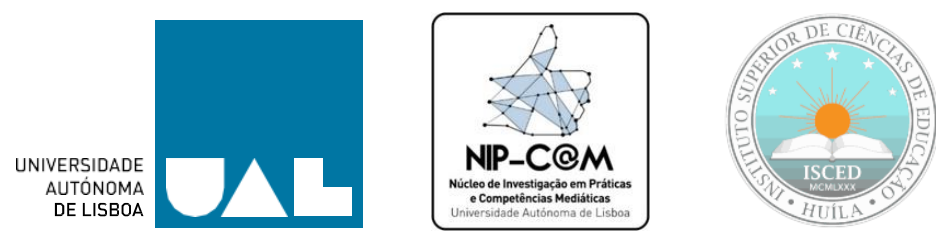


\section{Índice}

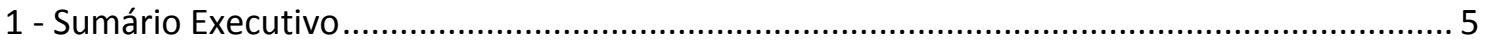

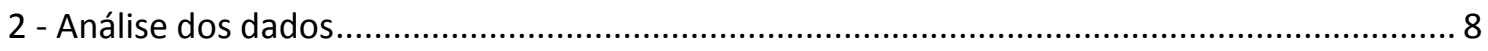

2.1 - Caraterização social e demográfica dos inquiridos............................................................ 8

2.2 - Tempo e dispositivos de navegação na Internet ............................................................. 12

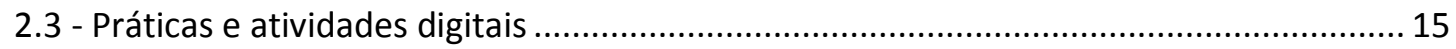

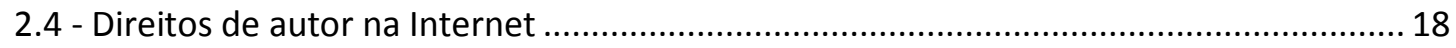

2.5 - Gestão e práticas nas redes sociais online ……............................................................... 19

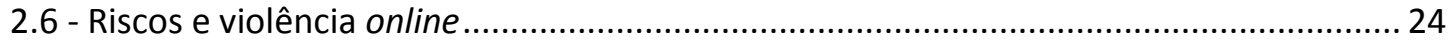

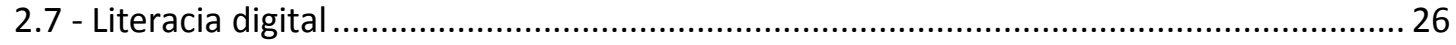

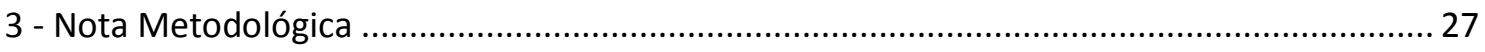

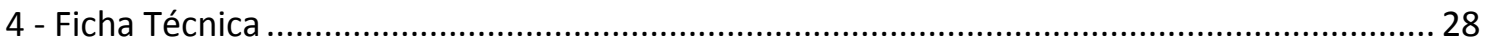




\section{Índice de Figuras}

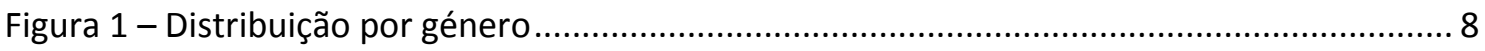

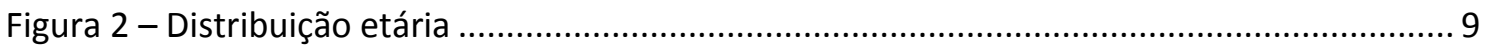

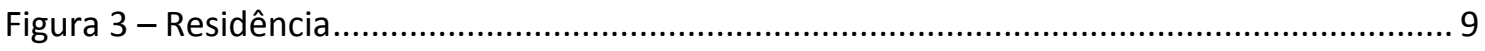

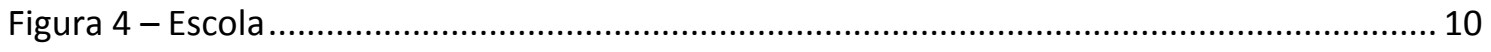

Figura 5 - Escolaridade do Pai e Mãe dos inquiridos ................................................................. 10

Figura 6 - Situação perante o trabalho do Pai e Mãe dos inquiridos ......................................... 11

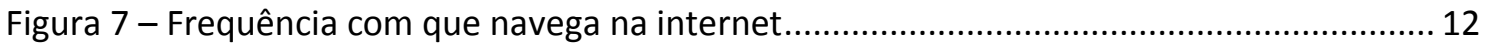

Figura 8 - Número de horas diárias de navegação na internet ................................................... 13

Figura 9 - Dispositivo com que acede à internet ..................................................................... 14

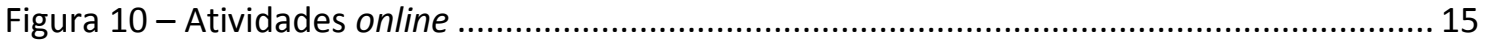

Figura 11 - Frequência de Práticas online (todos os dias) ......................................................... 16

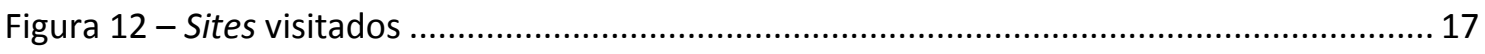

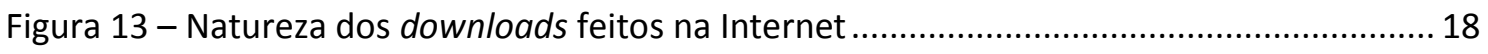

Figura 14 - Conhece os "direitos de autor na Internet" ........................................................... 19

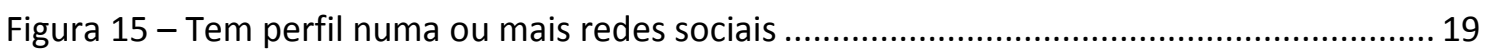

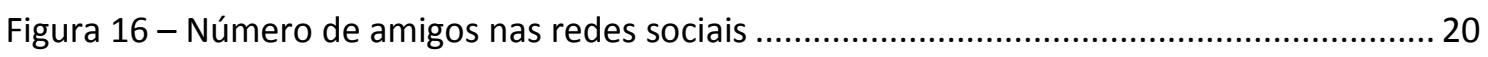

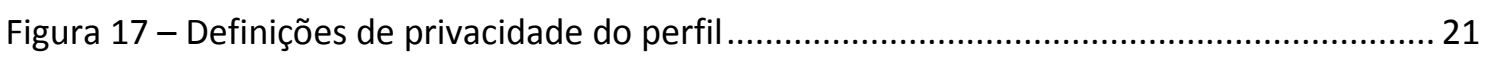

Figura 18 - Informações partilhadas nas redes sociais............................................................. 21

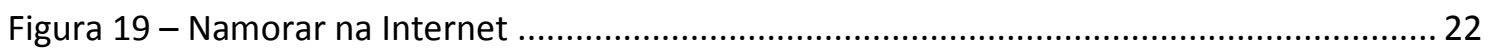

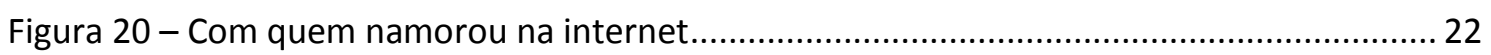

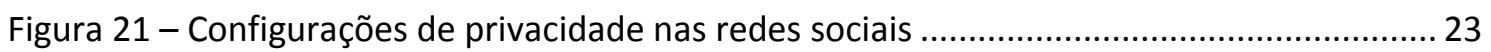

Figura 22 - Conhece alguém que sofreu violência e coação nas redes sociais ........................... 24

Figura 23 - Já experienciou as seguintes situações nas redes sociais ........................................ 25

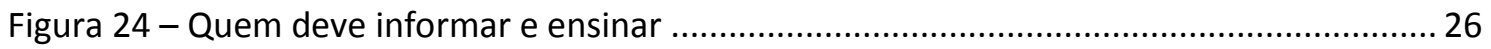




\section{1 - Sumário Executivo}

Este relatório expõe os resultados de um inquérito por questionário aplicado a jovens angolanos. Esta investigação, realizada por investigadores do Núcleo de Investigação em Práticas e Competências Mediáticas - NIP-COM da Universidade Autónoma de Lisboa, insere-se num projeto mais amplo, que tem como propósito estabelecer uma rede de investigação em Competências Mediáticas em distintos países, abarcando numa primeira fase diferentes realidades e contextos de Portugal, México, Cabo Verde, Angola e Moçambique.

O principal eixo norteador do Núcleo passa pelo estudo de práticas e competências mediáticas digitais e uso juvenil das Tecnologias de Informação e Comunicação (TIC), estudando as oportunidades, riscos e danos associados a esses usos. Deste modo, os objetivos passam por: a) identificação de conjuntos de práticas e de consumos mediáticos e digitais, nomeadamente ao nível da produção de conteúdos; b) identificação/explicação de situações de risco e vulnerabilidades no mundo digital, como o ciberbullying, o roubo de perfis e de dados nas redes sociais, a exposição a conteúdos violentos e/ou a conteúdos eróticos ou pornográficos; c) compreensão de consumos noticiosos e consumos culturais realizados por via digital; d) Perceção de atitudes face aos novos media; e) descodificação de sociabilidades decorrentes do processo de interação dos indivíduos na esfera digital; f) tipificação de práticas dos indivíduos nas redes sociais, nomeadamente ao nível da economia da partilha e das práticas colaborativas; g) realização de análise de conteúdo de espaços/projetos digitais; h) avaliação de competências mediáticas dos indivíduos no uso das tecnologias.

Este documento que agora se apresenta sintetiza dados recolhidos por inquérito por questionário, aplicado a alunos de várias escolas angolanas, num estudo realizado em parceria com a Escola Superior de Ciências da Educação - Húla, coordenado pelo professor Helder Bahu, cujos resultados permitem configurar os seguintes aspectos : a) caraterizar os alunos, circunstâncias sociais e profissionais dos progenitores; c) perceber o tempo dedicado diariamente à navegação na internet; d) discernir os dispositivos que são utilizados; e) identificar as atividades preferidas; f) apreender quais as práticas digitais mais frequentes; $\mathrm{g}$ ) mapear os principais sites e motores de busca utilizados; $h$ ) identificar as práticas e estratégias de gestão da presença nas redes sociais digitais; i) compreender as perceções e práticas de risco digital.

No que concerne à metodologia, optámos por uma aproximação de natureza quantitativa com aplicação de um inquérito por questionário num total de 27 questões, obtendo-se uma amostra de 1715 inquéritos validados. A maioria das questões que compõem o guião de 
inquérito é de natureza fechada, contudo existem exceções, que se justificam em face da maior riqueza e diversidade das respostas ${ }^{1}$.

Em termos orgânicos, o presente documento é composto por Sumário Executivo, Análise de Dados, Nota Metodológica e Ficha Técnica. A Análise de Dados subdivide-se em diversas secções: caraterização social e demográfica, tempo de navegação na internet e dispositivos utilizados, práticas e atividades digitais, direitos de autor na Internet, gestão e práticas nas redes sociais digitais e riscos e violência online. A exposição dos dados será apoiada pelo recurso a figuras que permitem ilustrar os dados.

\section{Síntese dos principais resultados:}

- Estamos perante uma população maioritariamente masculina, embora não discriminativa, com a diferença entre géneros a cifrar-se nos 4,2 pontos percentuais. A idade média dos inquiridos aproxima-se dos 17 anos.

- Os dois bairros com maior representatividade entre a amostra são: Dr. António Agostinho Neto/Lage com $11,6 \%$ e Comandante Nzaji 10,1\%. Em termos de escola frequentada, é no Instituto Médio de Economia do Lubango "121" que estudam 62,5\% dos inquiridos.

- As habilitações literárias têm em geral uma distribuição relativamente simétrica, embora a categoria modal para os pais seja a licenciatura com 19,9\%, já para as mães este indicador localiza-se no Ensino Médio com 22\%. Aproximadamente, 2/3 dos inquiridos têm o pai e mãe a trabalhar.

- Aproximadamente $2 / 3$ dos inquiridos diz aceder à internet "todos os dias". Diariamente, quase $27 \%$ ronda as $3 \mathrm{~h}$ diárias dedicadas à navegação, e no total quase $90 \%$ dizem fazê-lo com recurso ao telemóvel $(89,2 \%)$.

- As atividades realizadas online preferidas são: participar em redes sociais $(58,7 \%)$, procurar informação para trabalhos escolares $(35,9 \%)$. Em termos de frequência de realização é também a participação em redes sociais online $(45,7 \%)$, o envio de emails $(12,5 \%)$ e a procura de trabalhos escolares (10\%). Os sites mais visitados são os da marca Google, YouTube e a Wikipedia.

- Os downloads feitos na internet são para mais de $3 / 4$ dos inquiridos legais. Aproximadamente, $65 \%$ dos inquiridos admite não conhecer os direitos de autor na internet.

- Ascende a $90 \%$ dos inquiridos, aqueles que marcam presença em pelo menos uma rede social online. O número de amigos nestas plataformas permite-nos vislumbrar dois grupos que têm o

\footnotetext{
${ }^{1}$ Dois exemplos são os minutos de navegação na internet a nível diário, bem como a identificação dos sites preferidos.
} 
número de amigos superior a 2500 (33\%) e os que têm menos de 500 amigos (28,6\%).

- Quase 60\% dos inquiridos refere que o perfil é "público, toda a gente pode ver". As informações mais comummente partilhadas são fotografias $(79,6 \%)$, o nome verdadeiro $(51,6 \%)$ e a idade verdadeira $(36,7 \%)$. A maioria diz ainda não ter namorado na internet. Entre os que dizem já o ter feito, fizeram-no com amiga(o) (32,4\%). Mais de $1 / 3$ diz não terem mudado as configurações de privacidade.

- Existe uma clara tendência de maior perceção e denuncia de situações de risco online vividos por terceiros, comparativamente àquelas vividas na primeira pessoa, com valores tendencialmente mais reduzidos. Ainda assim, o contacto com conteúdos eróticos e/ou pornográficos é a situação mais recorrente.

- A família $(67,9 \%)$ é de longe o agente socializador ao qual é imputada maior responsabilidade na transmissão e ensino de práticas e competência no âmbito da literacia digital. 


\section{2 - Análise dos dados}

A linha de raciocínio seguida no presente documento é fundamentalmente de natureza expositiva e descritiva. Desta forma, excluímos qualquer tipo de inferência ou tentativa de construção de um modelo de análise que articule uma interpretação da totalidade dos dados. Com isto, pretende-se apresentar as linhas gerais dos resultados obtidos, de um estudo que necessariamente requer maior aprofundamento dos investigadores e demais interessados.

Com efeito, fica ao dispor do público em geral os dados genéricos obtidos no âmbito da presente pesquisa. No fundo, esta é mais uma iniciativa de divulgação e outreach que a Universidade Autónoma leva a cabo, num claro compromisso com a comunidade envolvente.

\section{1 - Caraterização social e demográfica dos inquiridos}

Na presente seç̧ão serão expostos, de forma breve, os resultados essenciais e genéricos que permitem caraterizar social e demograficamente os inquiridos.

\section{Figura 1 - Distribuição por género}

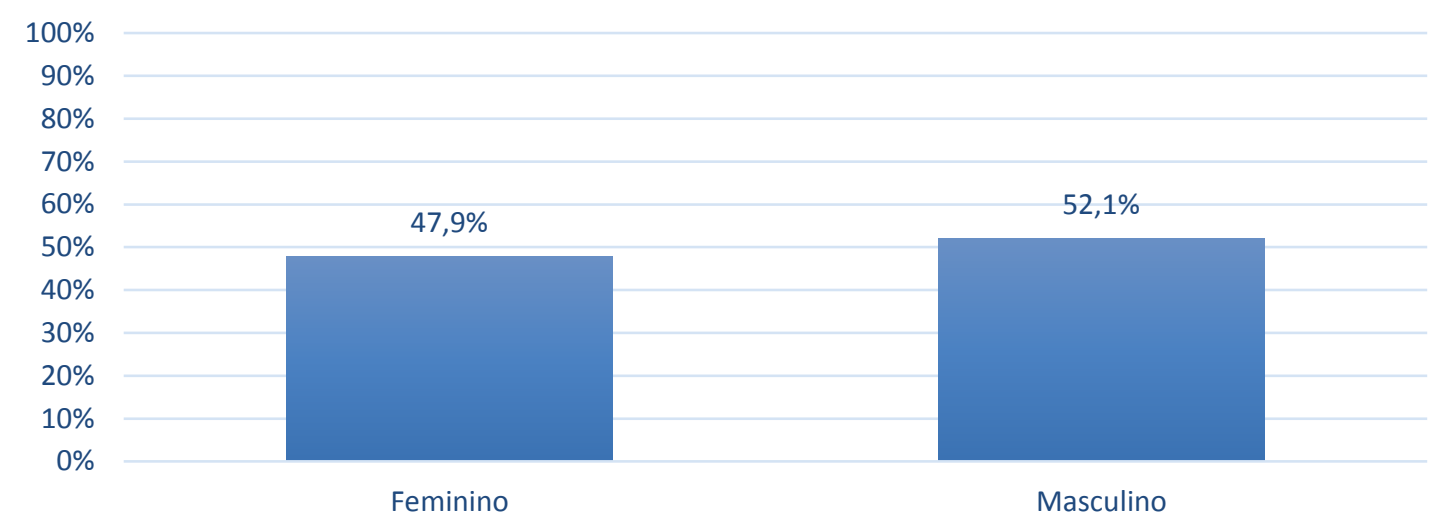

Fonte: Elaboração própria

A amostra é constituída por uma maioria de entrevistados do género masculino $(52,1 \%)$. 0 feminino fica-se pelos $47,9 \%$ (cf. Figura 1 ). 


\section{Figura 2 - Distribuição etária}

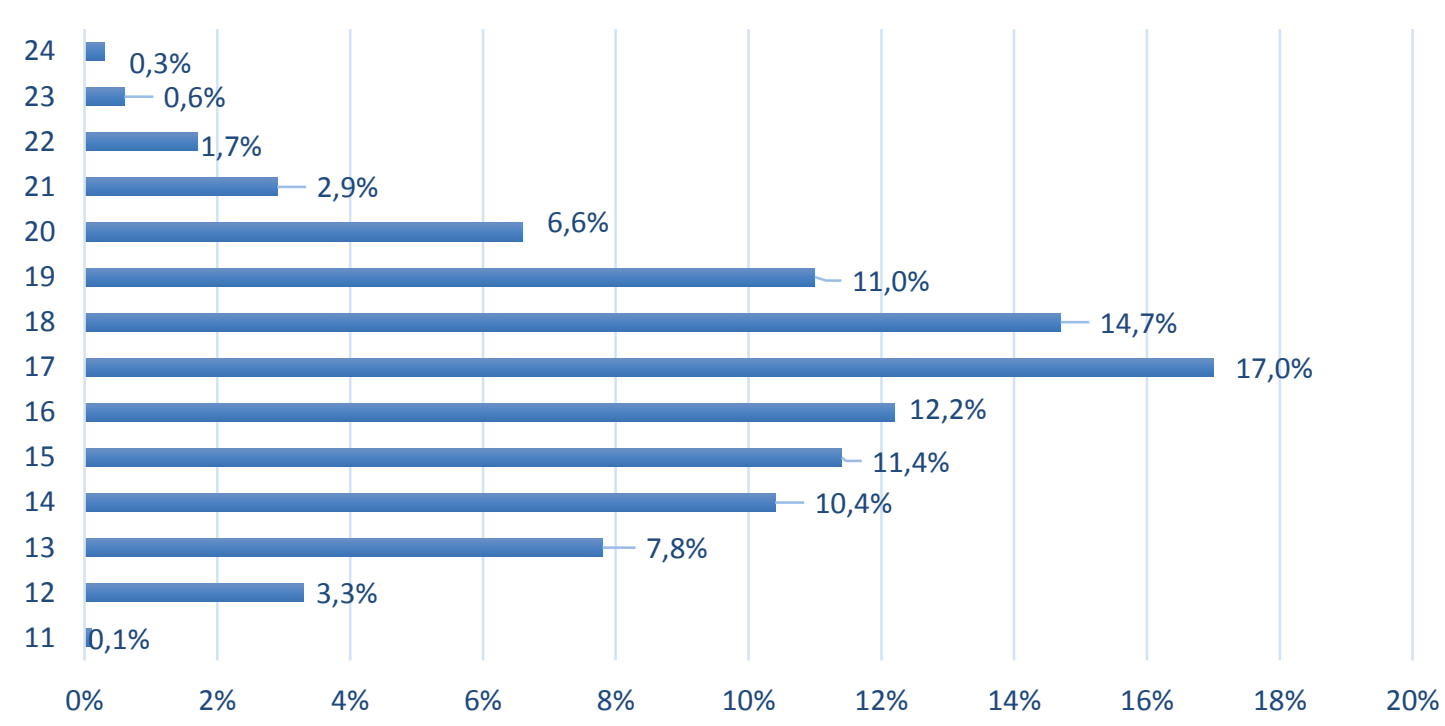

Fonte: Elaboração própria

Em termos etários (cf. Figura 2), o destaque vai para o facto de a idade média aproximada rondar os 17 anos. A amplitude etária tem o seu mínino nos 11 anos com 0,1\% dos inquiridos e uma idade máxima de 24 anos para 0,3\%. A idade modal cifra-se nos 17 anos com 17,0\%.

\section{Figura 3 - Residência}

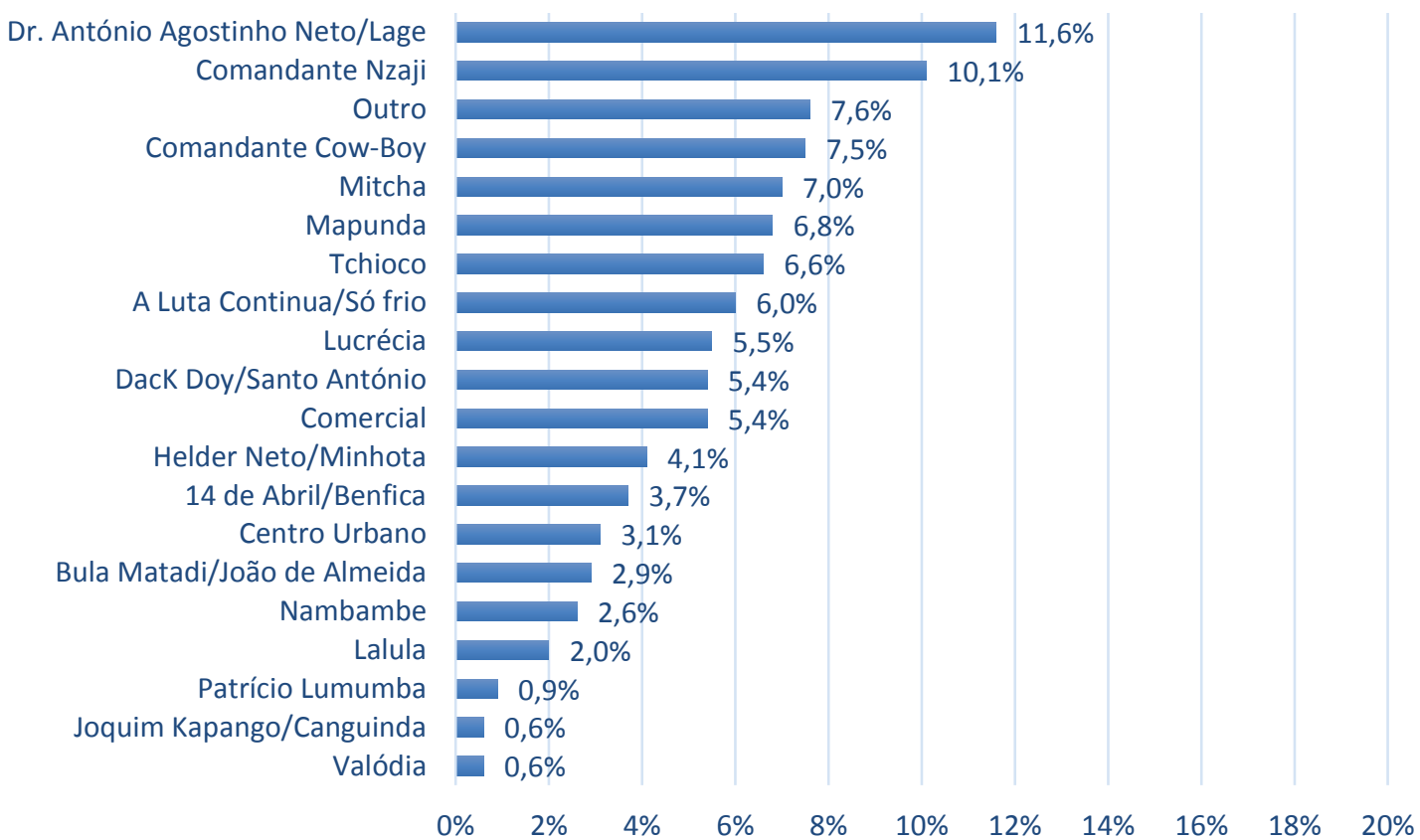

Fonte: Elaboração própria 
Existe alguma dispersão quanto ao bairro ou ária de residência dos inquiridos (cf. Figura 3). No bairro Dr. António Agostinho Neto residem cerca 11,6\% dos inquiridos. Com registo acima dos dois dígitos, apenas Bairro Comandante Nzaji com 10,1\%. No Valódia, estes ascendem apenas a $0,6 \%$.

Figura 4 - Escola

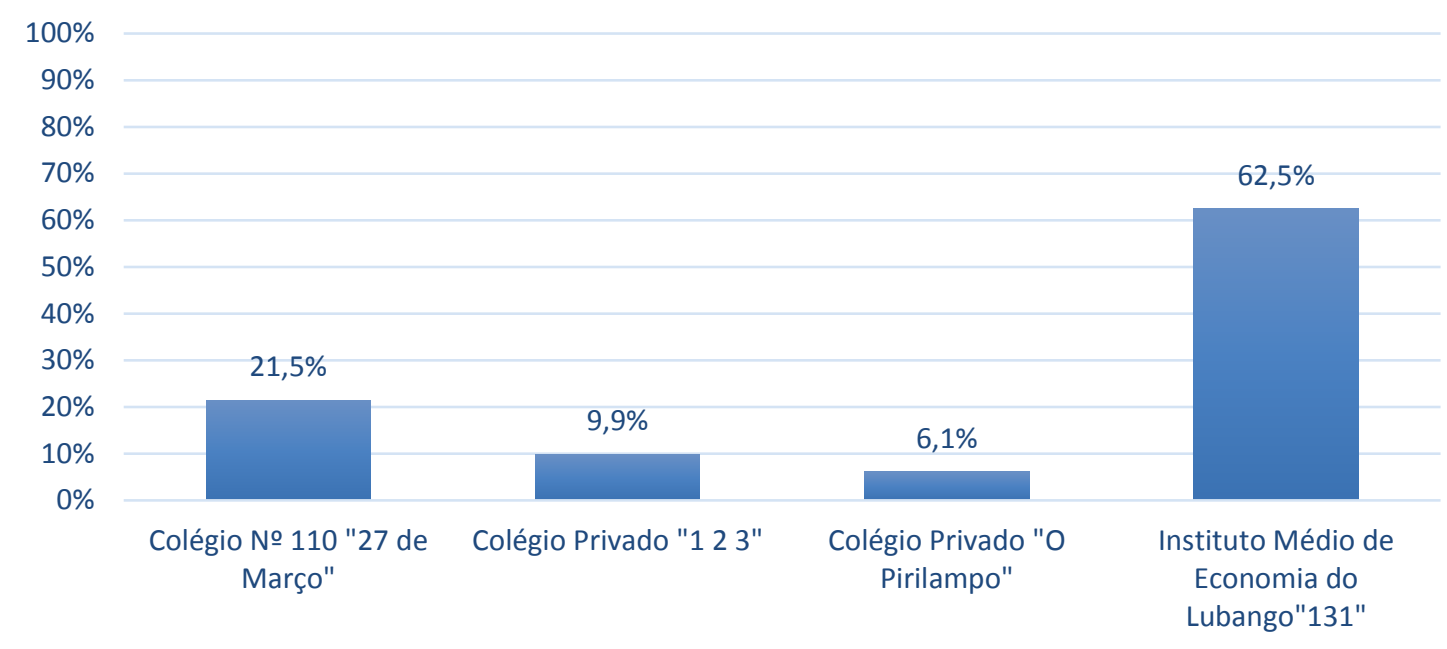

As escolas nas quais estudam os inquiridos circunscrevem-se a quatro (cf. Figura 4). 0 destaque vai para a o Instituto Médio de Economia do Lubango $131 \mathrm{com}$ mais de metade do total dos jovens inquiridos (62,5\%). Com valor ainda assinalável, o Colégio № 110 "27 de Março" com 21,5\%.

\section{Figura 5 - Escolaridade do Pai e Mãe dos inquiridos}

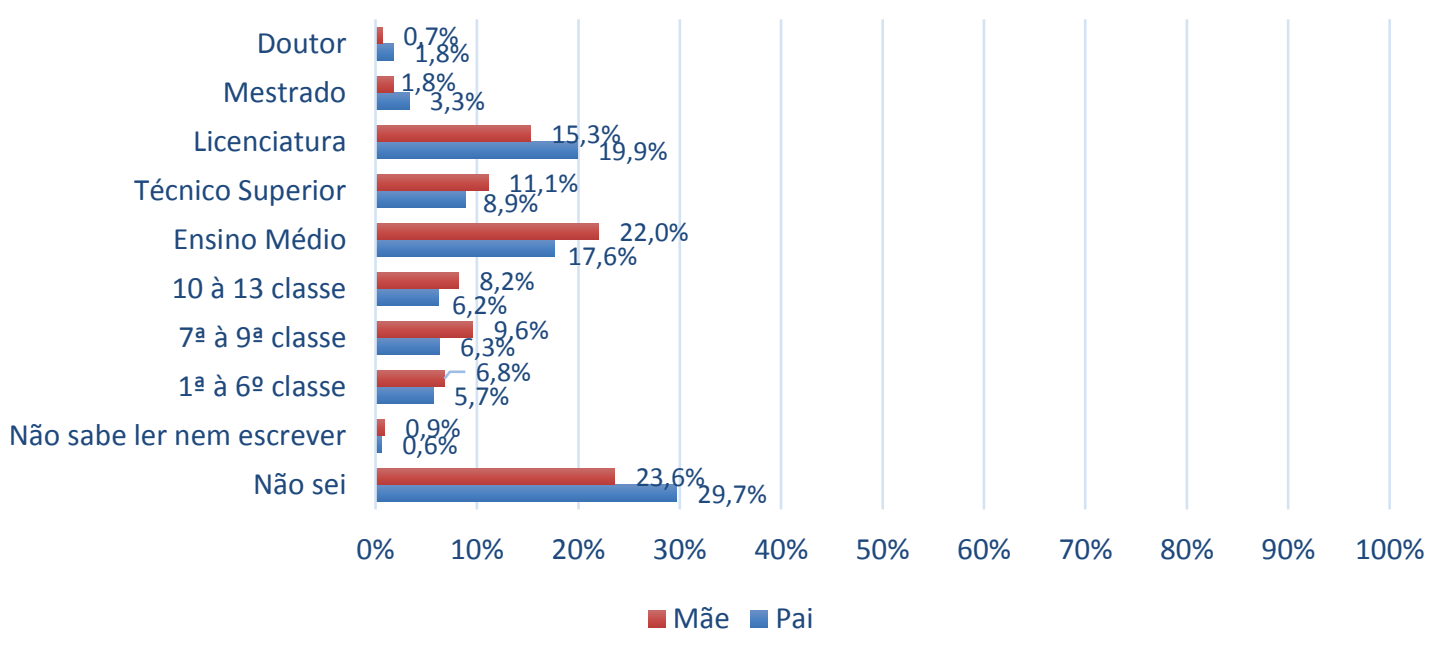

Fonte: Elaboração própria. 
Um aspeto relevante na caraterização social e que nos permite apreender melhor o quadro simbólico e cultural de origem dos inquiridos diz respeito à escolaridade dos pais. Desta forma, de acordo com a Figura 5 destaca-se o facto de a maioria dos pais terem a categoria modal no Ensino Médio ao registar 22\%. Relativamente aos pais, a categoria modal situa-se no nível de Licenciatura com 19,9\% (não considerando os valores de "não sei"). O que pode constituir-se como um indício de diferenças significativas entre os progenitores dos inquiridos. No entanto, devemos frisar os valores residuais relativamente ao "não sabe ler nem escrever", ao não ascender aos $1 \%$.

\section{Figura 6 - Situação perante o trabalho do Pai e Mãe dos inquiridos}

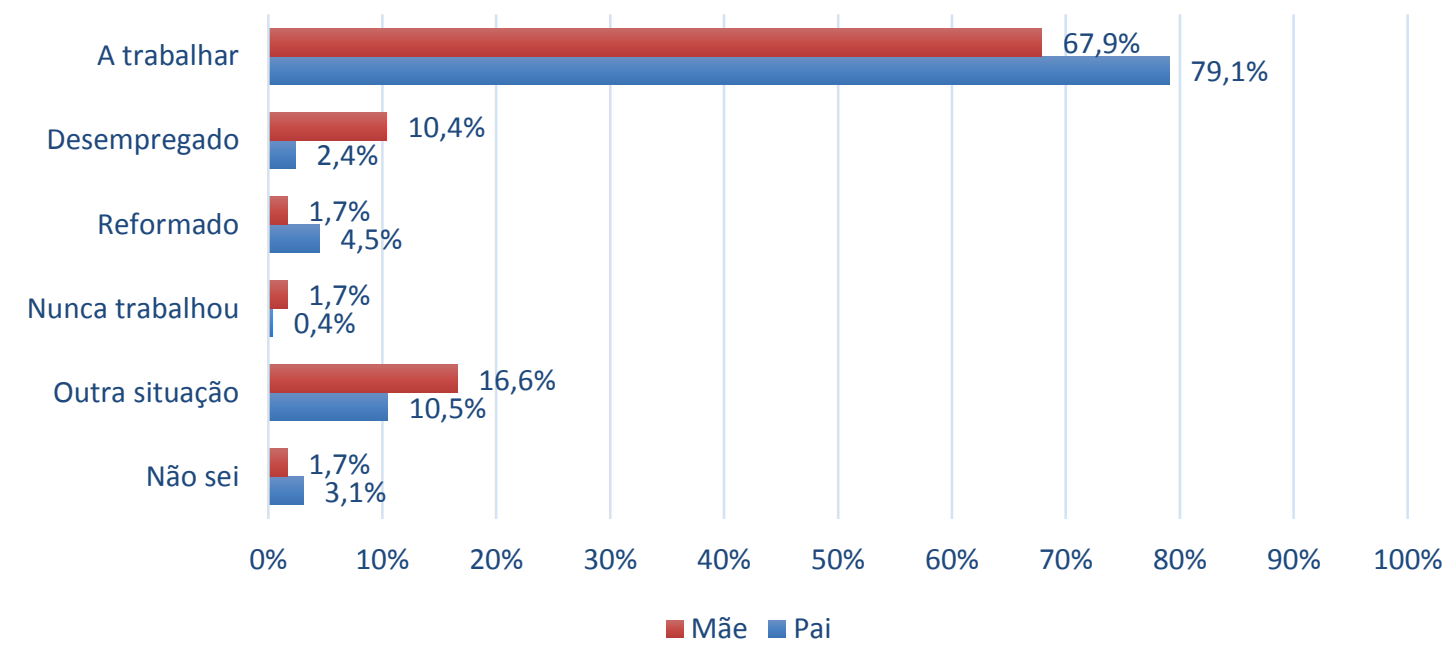

Fonte: Elaboração própria.

Na senda da caraterização dos progenitores dos inquiridos, os dados relativos à situação laboral são taxativos no que concerne à condição de trabalhadores no ativo, tanto em mães como pais rondando os $2 / 3$ e $4 / 5$ respetivamente (cf. Figura 6). A segunda categoria com maiores valores refere-se a "outra situação" em ambos os casos com 16,6\% para mães e 10,5\% para os pais. Em geral, pode dizer-se que as tendências são relativamente similares em ambos os sexos.

Em síntese, dir-se-á que os inquiridos que constituem a amostra são maioritariamente do sexo masculino, concentrando-se entre os 15 e 19 anos de idade. Distribuem-se por diversas áreas residenciais da cidade do Lubango. Na maioria dos inquiridos, os respetivos progenitores têm o Ensino Médio ou mesmo uma Licenciatura. Finalmente, a maioria dos inquiridos declara que os seus respetivos progenitores estão atualmente no ativo no mercado de trabalho. 


\section{2 - Tempo e dispositivos de navegação na Internet}

$\mathrm{Na}$ presente secção serão expostos dos dados, de forma genérica, relativos ao tempo disponibilizado diariamente na navegação na internet e a tipologia de dispositivos utilizados para essa mesma atividade.

\section{Figura 7 - Frequência com que navega na internet}

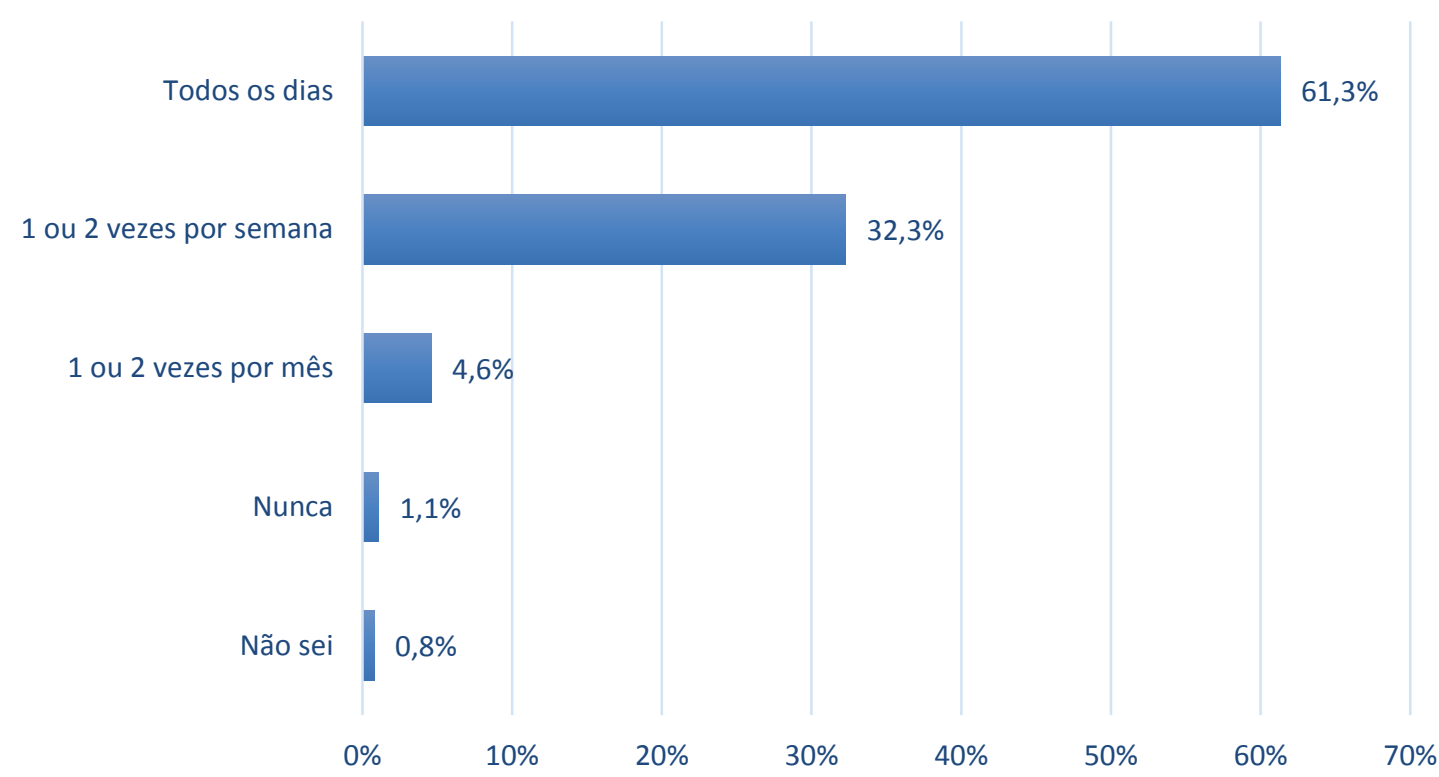

Fonte: Elaboração própria

Inicialmente era questionada a frequência com que acediam à internet (cf. Figura 7). Deste modo, $61,3 \%$ referem que o fazem todos os dias. A partir desta opção, aos inquiridos era solicitado que mensurassem quantitativamente o tempo despendido diariamente, nas várias tarefas que são realizadas nas mais diversas plataformas online. 


\section{Figura 8 - Número de horas diárias de navegação na internet}

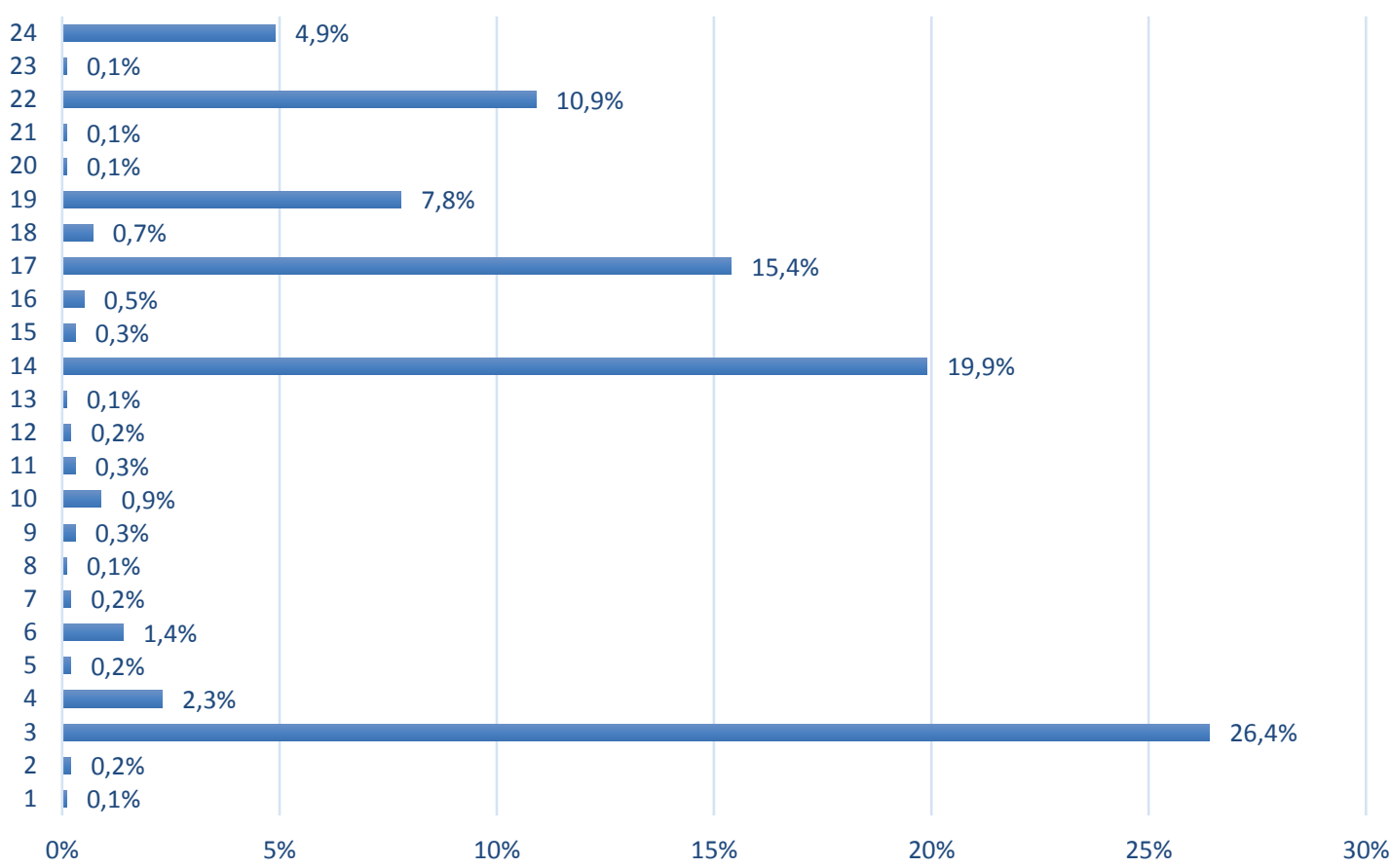

Fonte: Elaboração própria

A Figura 8 ilustra o tempo que os diversos inquiridos declaram mobilizar diariamente no desempenho das várias atividades na internet, em número de horas. Em termos médios, o registo diário de horas por inquirido aproxima-se das 13 horas. Embora este elevado valor médio, a moda situa-se nas 3 horas para 26,4\%. Já a mediana situa-se nas 14 horas diárias de navegação. 
Figura 9 - Dispositivo com que acede à internet

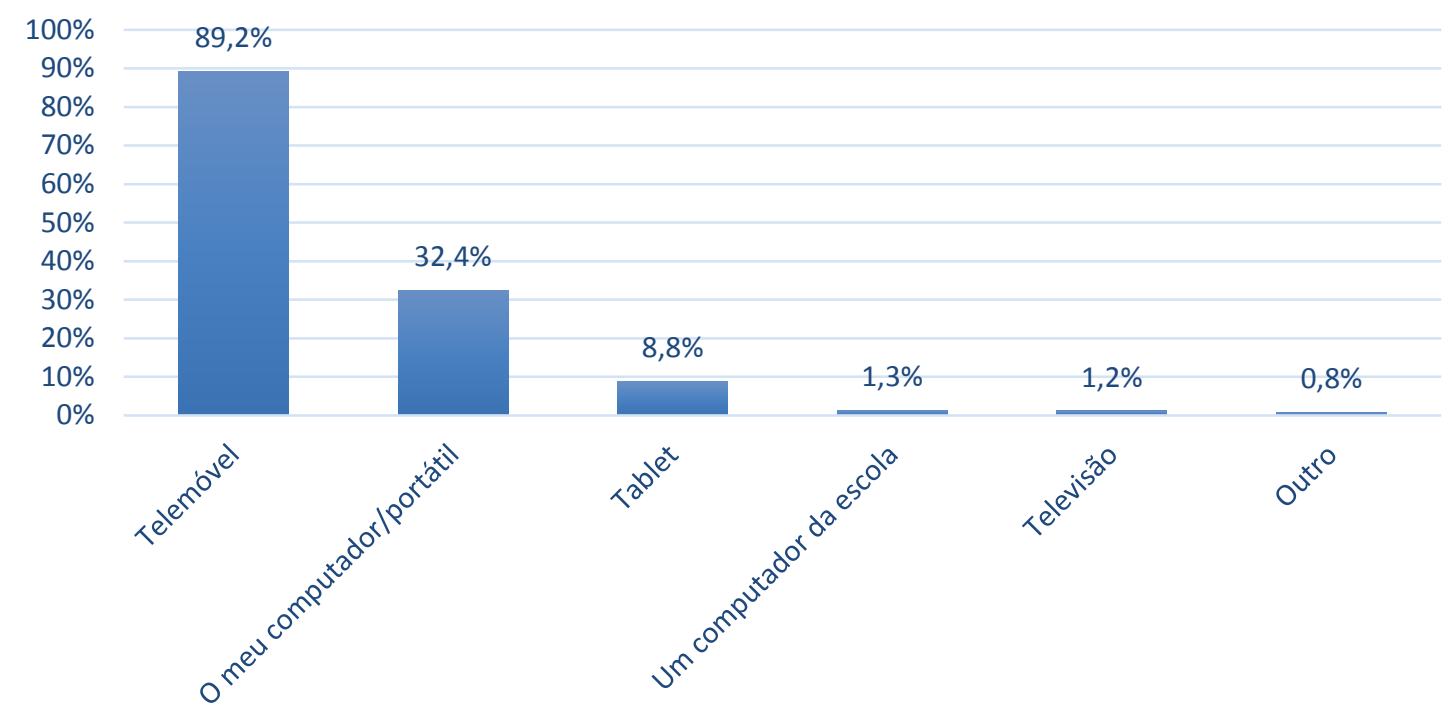

Fonte: Elaboração própria (resposta múltipla)

O dispositivo móvel surge em destaque entre os dispositivos utilizados para aceder e navegar na internet (cf. Figura 9). O telemóvel surge no topo das preferências com 89,2\%, seguido do portátil com apenas 32,4\%. A televisão surge como opção para 1,2\%.

Aproximadamente, $61,3 \%$ dos inquiridos declara navegar na internet "todos os dias". Entre estes, a maioria dedica até aproximadamente 13 horas diárias à realização de diversas tarefas no espaço digital, sendo que a moda é de 3 horas diários. Os dispositivos que permitem a portabilidade, como o telemóvel e o computador portátil, concentram a preferência dos inquiridos na hora de aceder à internet. 


\section{3 - Práticas e atividades digitais}

A presente secção versa sobre atividades realizadas no espaço digital, a sua frequência e ainda os sites mais frequentados pelos inquiridos.

\section{Figura 10 - Atividades online}

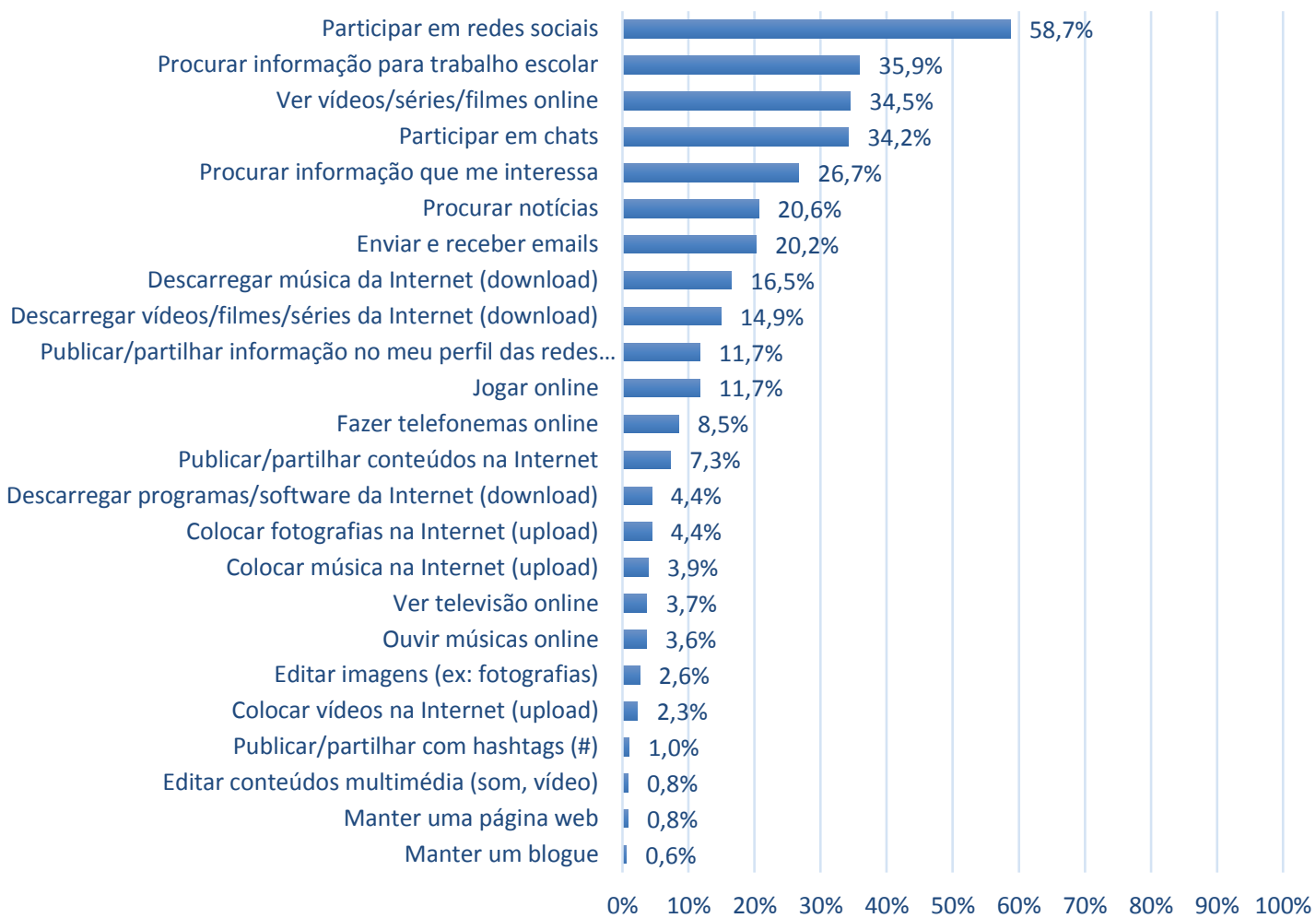

Fonte: Elaboração própria (resposta múltipla)

Uma das questões centrais da presente reflexão passava por indagar que práticas os inquiridos priorizam quando estão a navegar na internet. Aos inquiridos era dada a possibilidade de assinalarem as três principais atividades. Apenas uma "procurar informação para trabalho escolar" foi selecionada por mais de metade dos inquiridos $(50,1 \%)$. Destaque ainda para as suas seguintes: "procurar informação que me interessa" e "enviar e receber emails" com respetivamente $46,1 \%$ e $44,4 \%$. A restante distribuição empírica dos dados pulveriza-se pelas outras atividades digitais enunciadas. 


\section{Figura 11 - Frequência de Práticas online (todos os dias)}

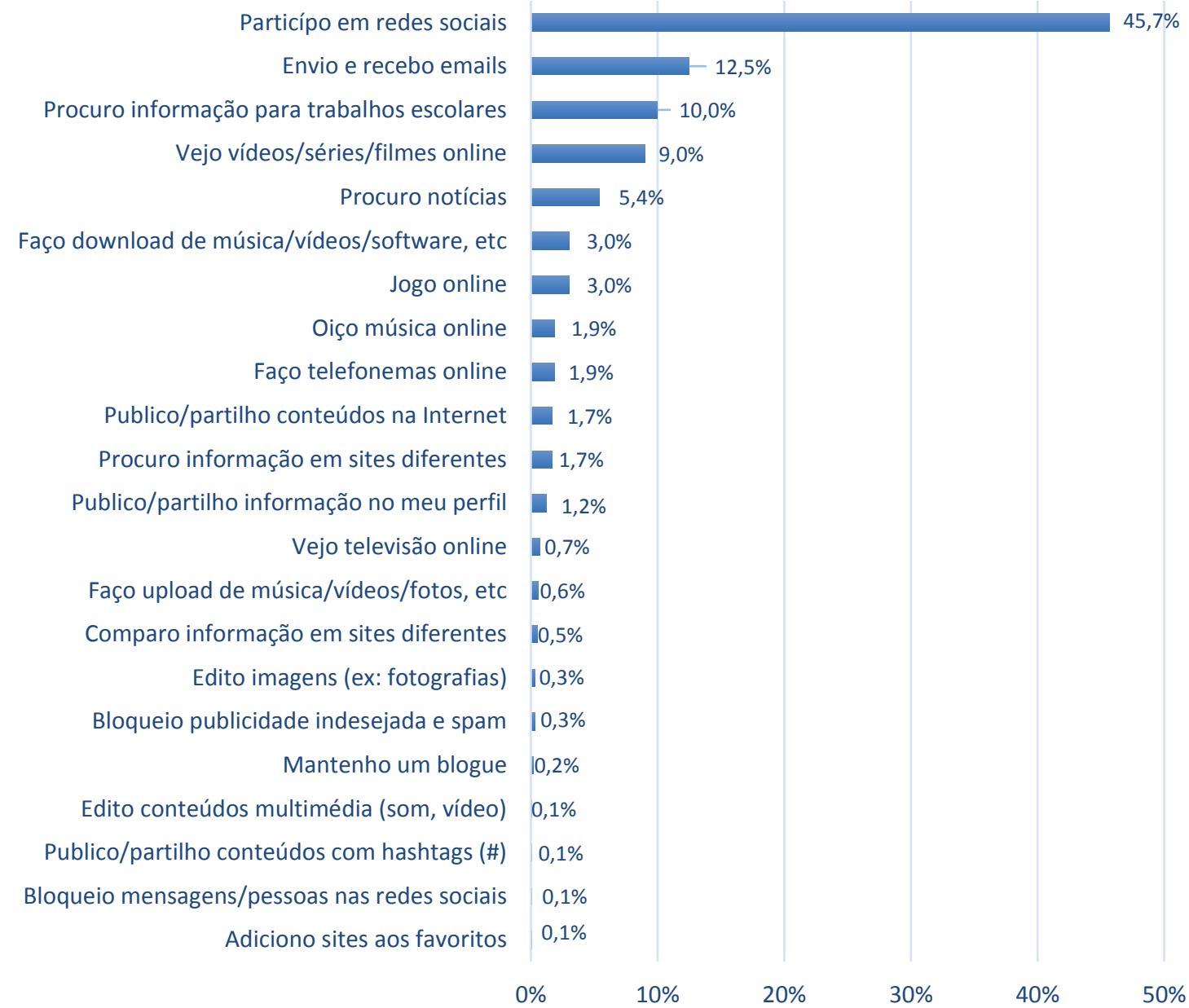

Fonte: Elaboração própria.

A bateria seguinte de questões versa sobre as atividades digitais e a frequência com que são realizadas. A representação gráfica desta questão está sintetizada na figura 11 com os registos das duas categorias polarizadoras (todos os dias e nunca). Deste modo, é percetível que "participo nas redes sociais" é aquela atividade que é realizada com maior frequência por parte de $45,7 \%$ dos inquiridos. No lote de práticas com maior frequência média encontram-se ainda "procuro informação para trabalhos escolares e "procuro notícias" com respetivamente $12,5 \%$ e 10,0\%. Nos antípodas desta situação, encontra-se "apago o registo dos sites que visitei", "altero as definições de privacidade nos sites" e "mantenho uma página web" todas elas com nenhum inquirido a fazê-lo diariamente.

A figura seguinte (cf. Figura 12) ilustra a distribuição empírica dos dados resultante da questão que indagava os inquiridos sobre os sites mais acedidos por aqueles. Deste modo, observa-se que o Google é a plataforma mais utilizada (48,3\%). Uma tentativa de aproximação a uma explicação será considerar este motor de busca como o ponto de partida para a efetiva 
navegação, incluindo a utilização de aplicações e ferramentas associadas à marca Google como o Chrome. Com registos assinaláveis surgem também redes sociais como YouTube $(14,3 \%)$ Facebook com 6,1\%.

Figura 12 - Sites visitados

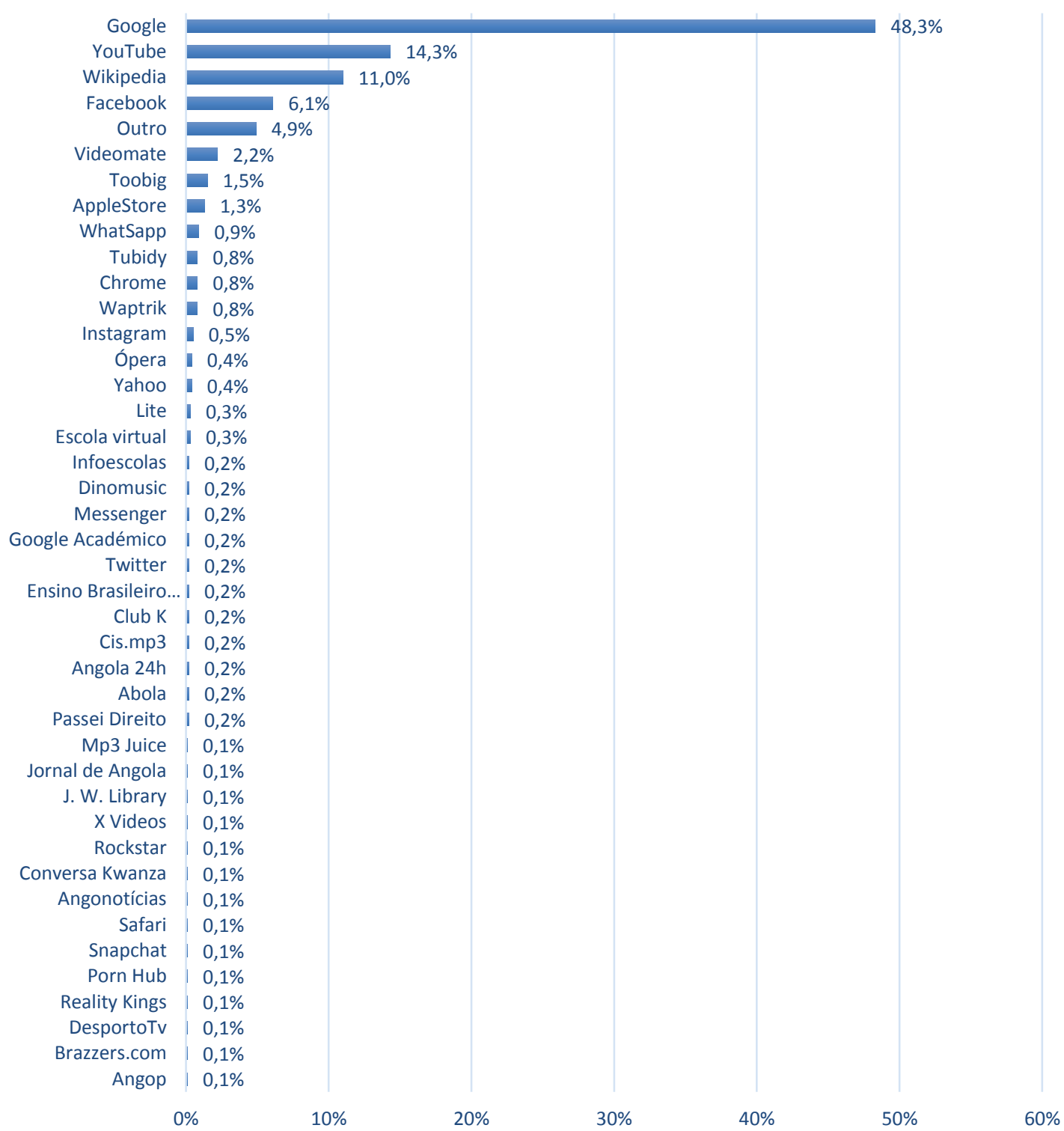

Fonte: Elaboração própria (resposta múltipla)

O âmago da presente secção está na avaliação das atividades realizadas e sua frequência. Nesse sentido e olhando de forma muito genérica os dados, verificamos que existem práticas de complexidade mais elementar entre as mais frequentes e mais complexas entre aquelas 
com menor frequência entre os inquiridos. Os sites mais visitados versam sobretudo em torno do motor de busca Google e algumas das suas ferramentas.

\section{4 - Direitos de autor na Internet}

A secção que agora se inicia é composta por apenas duas questões que têm como denominador comum a abordagem às perceções que os inquiridos têm acerca dos direitos de autor relativamente a conteúdos que se encontram nas plataformas online.

Figura 13 - Natureza dos downloads feitos na Internet

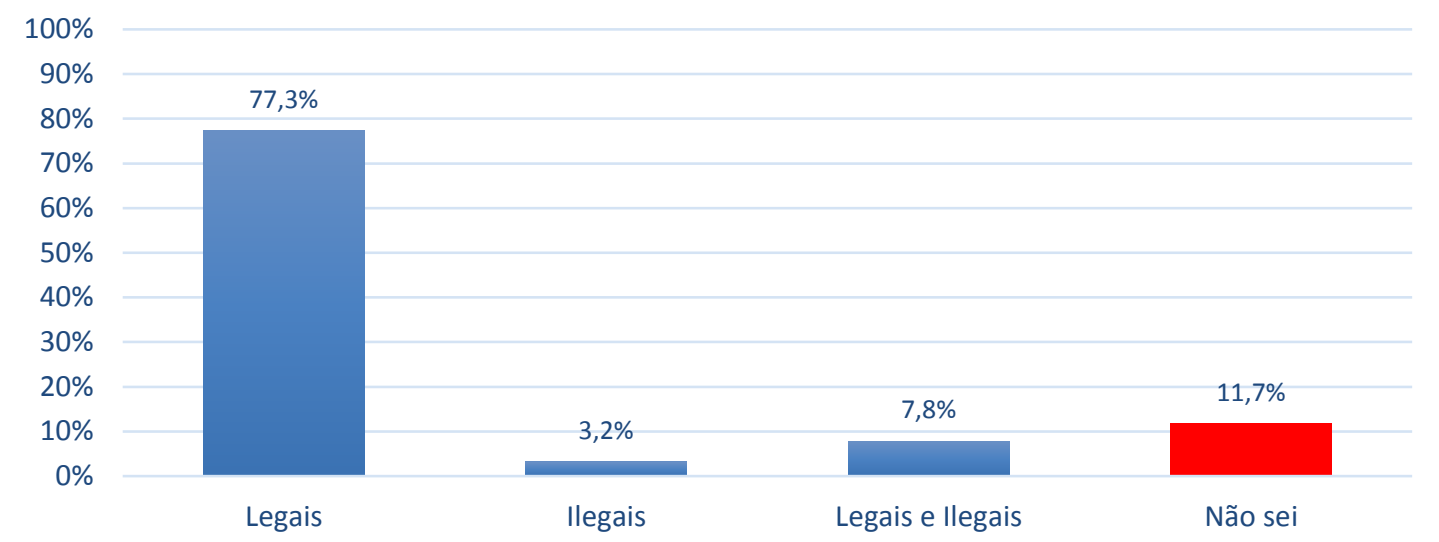

Fonte: Elaboração própria

Ascende a mais de $3 / 4$, mais precisamente $77,3 \%$ dos inquiridos, aqueles que declaram que os downloads que fazem, a partir de plataformas online, têm uma natureza estritamente legal (cf. Figura 13). Antagonicamente cifra-se em apenas $3,2 \%$, os inquiridos angolanos deste estudo que mencionam fazer downloads ilegais. 


\section{Figura 14 - Conhece os "direitos de autor na Internet"}

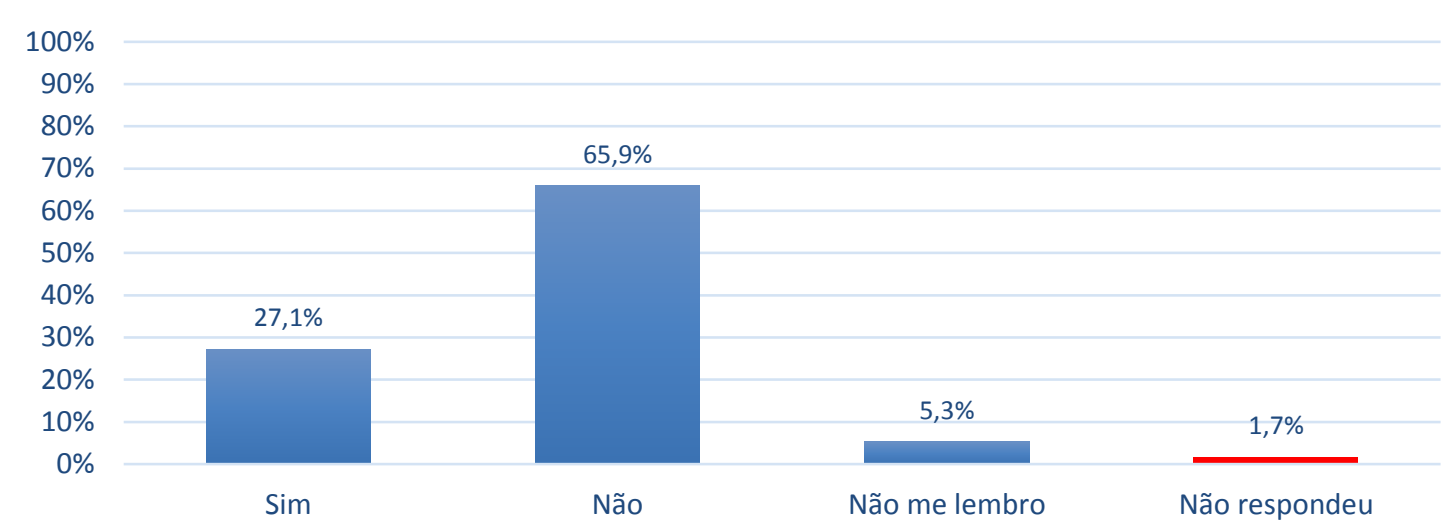

Fonte: Elaboração própria

Cifra-se em aproximadamente $1 / 4(27,1 \%)$ os inquiridos que mencionam conhecer os direitos de autor na internet (cf. Figura 14). A maioria, 65,9\%, assumem não ter conhecimento da legislação em vigor relativamente a direitos de autor na internet. A perceção geral dos inquiridos assume o desconhecimento relativamente aos direitos de autor vigentes no espaço online.

\section{5 - Gestão e práticas nas redes sociais online}

A secção que se inicia agora tem como objetivo descrever os dados obtidos acerca das questões que operacionalizam a gestão e os procedimentos dos inquiridos no seio das redes sociais online.

Figura 15 - Tem perfil numa ou mais redes sociais

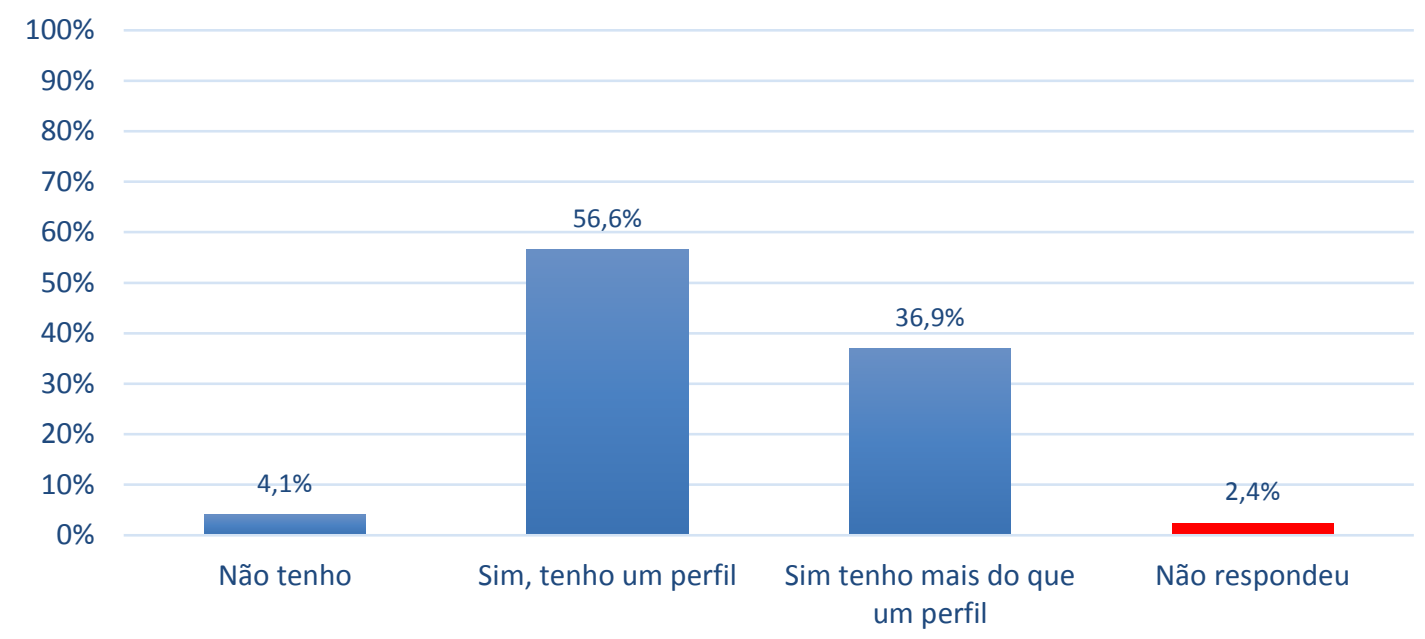

Fonte: Elaboração própria 
$56,5 \%$ dos inquiridos declararam que têm perfil numa rede social digital (cf. Figura 15). Quase $37 \%$, mais precisamente $36,9 \%$, dizem estar presentes em duas ou mais redes sociais digitais. Desta forma, é residual o número de inquiridos que não está presente nas redes sociais online $(4,1 \%)$ com pelo menos um perfil.

\section{Figura 16 - Número de amigos nas redes sociais}

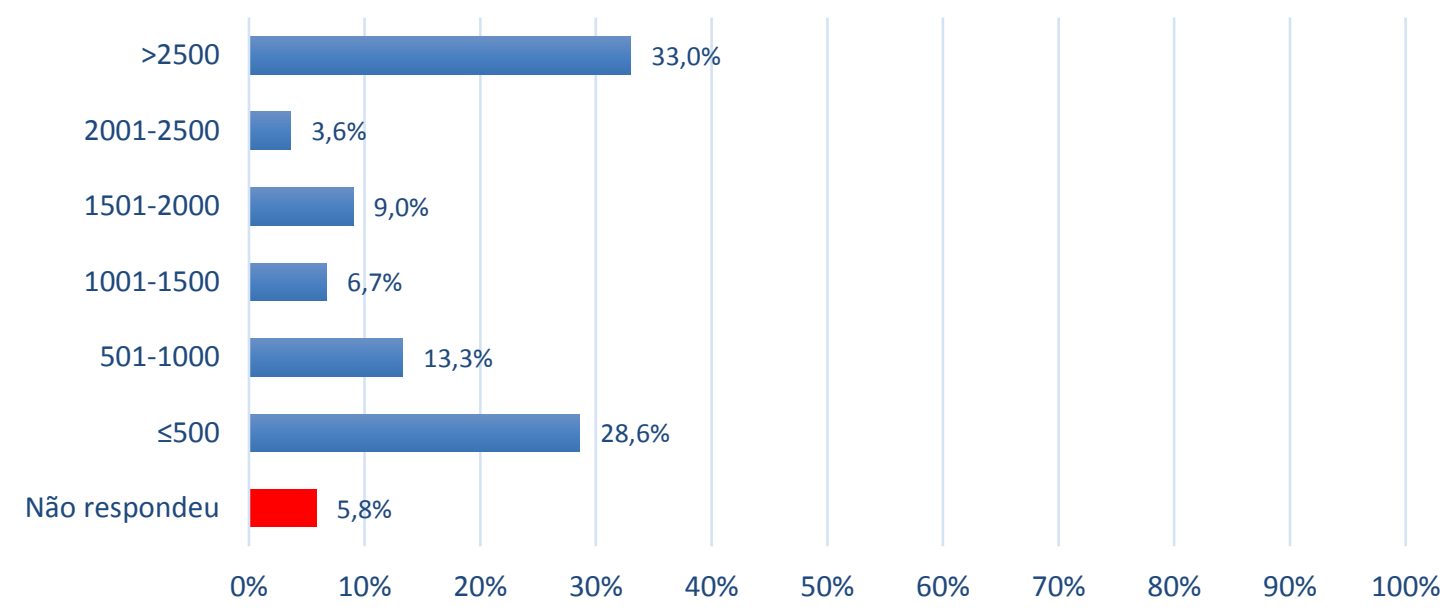

Fonte: Elaboração própria

Quanto ao número de "amigos" que estes jovens dizem ter nas redes sociais online, a distribuição empírica dos dados da amostra tem a sua categoria modal no registo que contempla um número superior a 2500 amigos, albergando um 33\% das respostas dadas (cf. Figura 16). Por outro lado, há também $28,6 \%$ de inquiridos que dizem ter cerca de 500 "amigos" neste tipo de plataformas. Salientamos ainda que cerca de 5,8\% decidiu não responder. 
Figura 17 - Definições de privacidade do perfil

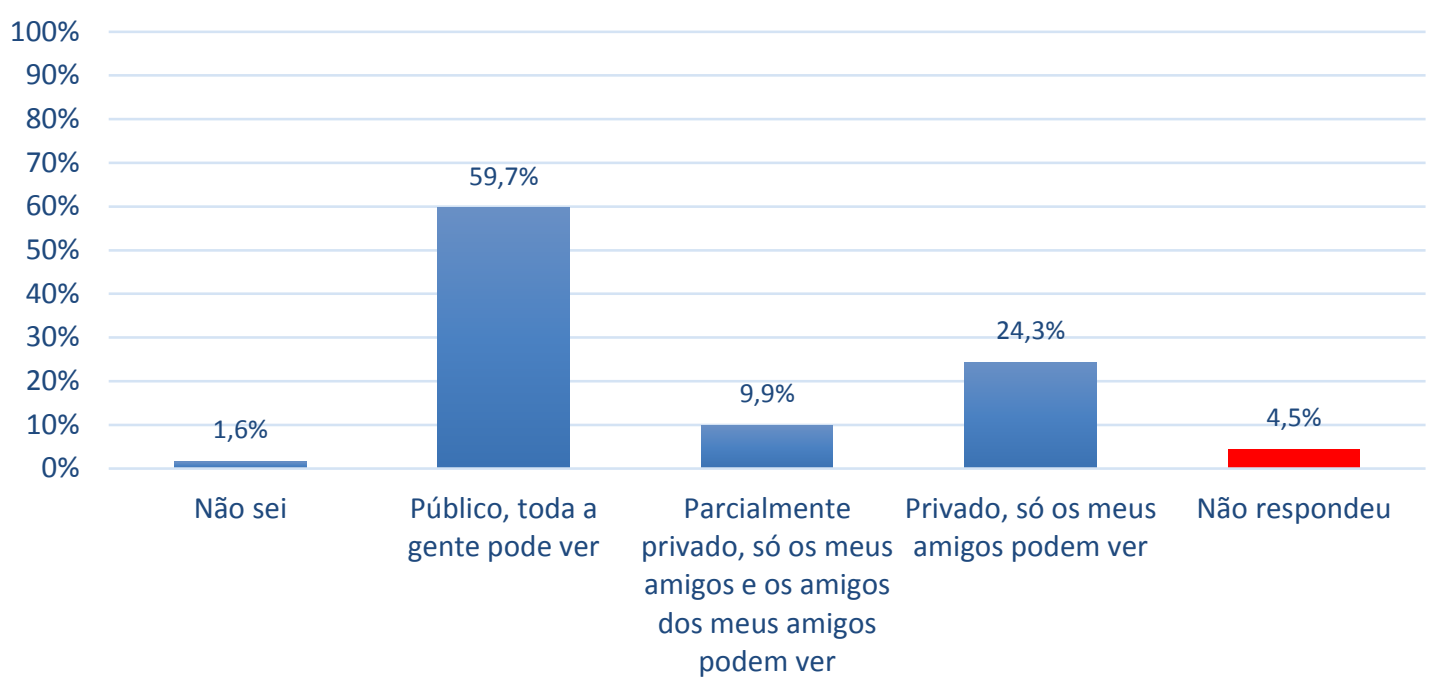

Fonte: Elaboração própria

A maioria, mais precisamente $59,7 \%$, são aqueles que dizem que tudo o que publicam é explicitamente público, não alterando a configuração dos critérios de privacidade. Cerca de 9,9\% dizem que parcialmente tornam público os conteúdos que partilham nas redes sociais digitais e $24,3 \%$ dizem fazê-lo apenas para amigos (cf. Figura 17).

\section{Figura 18 - Informações partilhadas nas redes sociais}

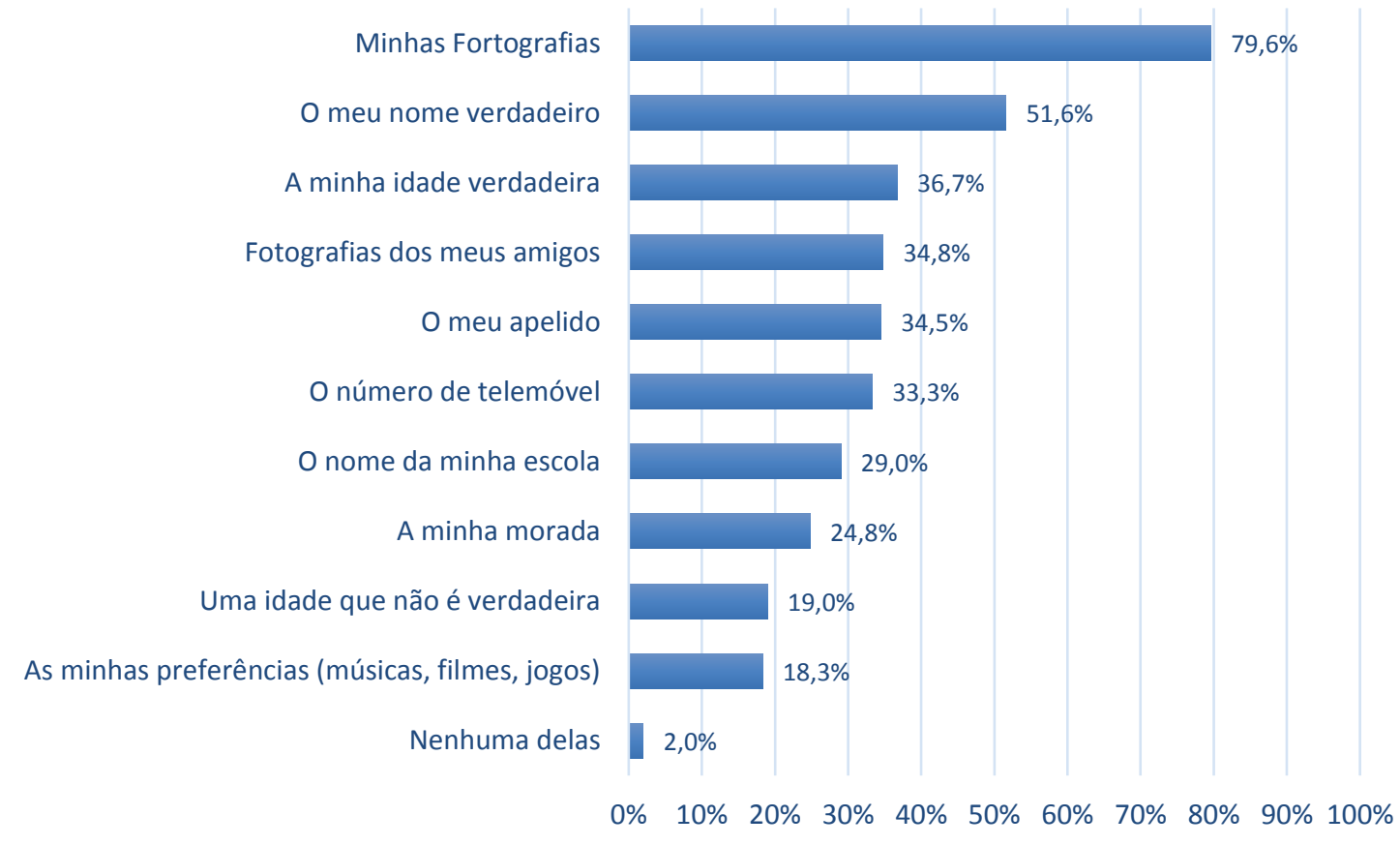

Fonte: Elaboração própria (resposta múltipla) 
Neste role de questões tentámos perceber que tipo de conteúdos são partilhados. Os dados contidos na Figura 18 são claros a esse nível: 79,6\% dizem partilhar fotografias, claramente o tipo de conteúdo mais partilhado nesta amostra, seguido do "nome verdadeiro" com 51,6\%. Com $36,7 \%$ surge a "idade verdadeira", depois registamos um $34,8 \%$ na partilha de "fotografias dos meus amigos" e o "apelido" e o "número de telemóvel" com respetivamente $34,5 \%$ e $33,3 \%$.

Figura 19 - Namorar na Internet

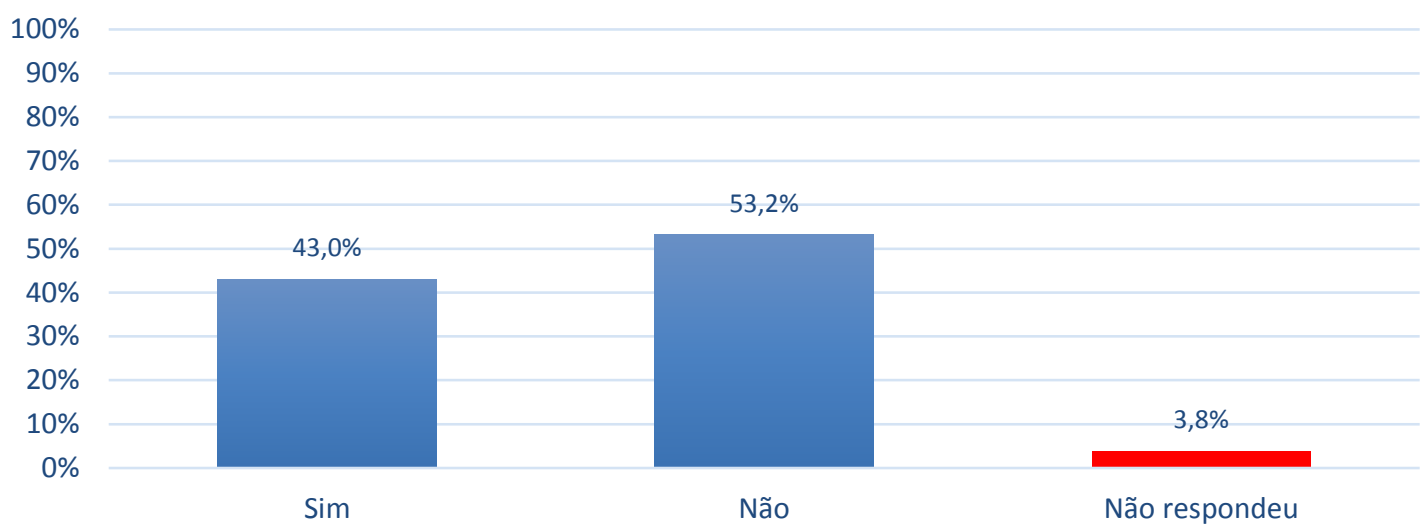

Fonte: Elaboração própria

Os dados contidos na Figura 19 revelam algum equilíbrio: cerca de 53,2\% dos inquiridos diz nunca ter namorado na internet, por seu lado 43\% referem já o terem feito.

\section{Figura 20 - Com quem namorou na internet}

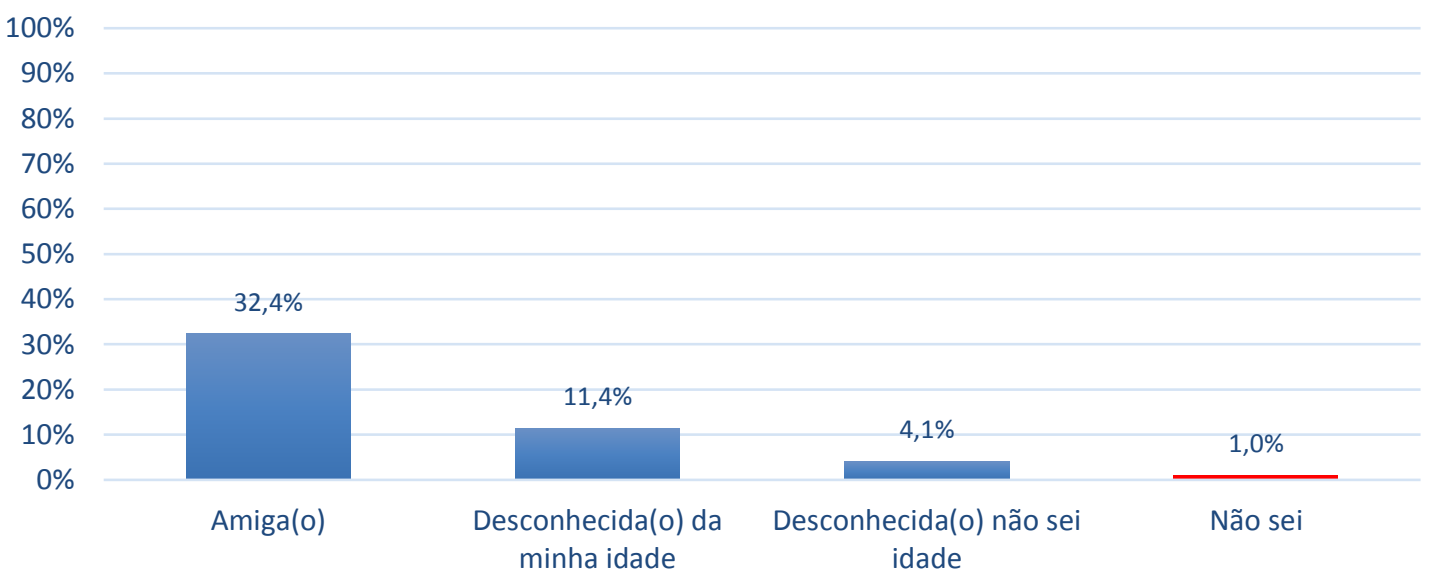

Fonte: Elaboração própria 
A jusante da questão anterior tentamos perceber com quem já namorou na internet. Os dados ilustrados na figura 20 indicam que uma parte considerável o fez com "amigo(a)" (32,4\%). $4,1 \%$ dos inquiridos assume tê-lo feito com alguém que the era desconhecido e cuja idade era uma incógnita.

\section{Figura 21 - Configurações de privacidade nas redes sociais}

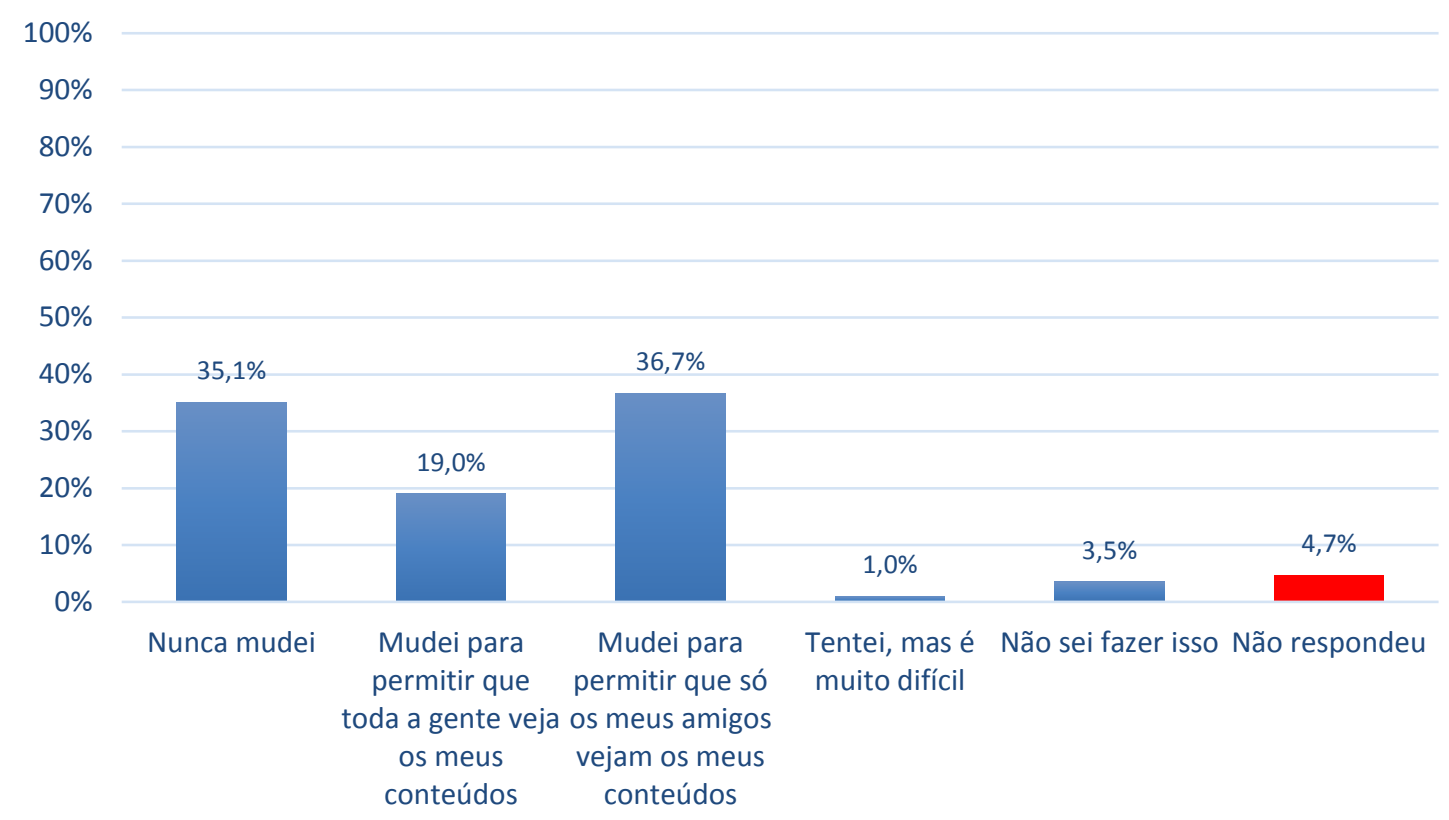

Fonte: Elaboração própria

Dos inquiridos, 35,1\% afirma nunca ter alterado as configurações de privacidade das redes sociais online onde tem conta (cf. Figura 21) e 4,5\% declara não saber como o fazer.

Em síntese, dir-se-á que aproximadamente $56,6 \%$ dos inquiridos declara ter conta numa rede social online. O número de "amigos" nas redes sociais diferencia dois grandes grupos, os que têm um número até 500 amigos e os que registam um valor superior a 2500 . 59,7\% dos inquiridos sabe que tem o perfil aberto para toda a gente ver. As fotografias de si próprio e o nome verdadeiro são as informações mais vulgarmente partilhadas nas redes sociais online. Ascende a $43 \%$ os inquiridos que assumem já ter namorado na internet fazendo-o tendencialmente com amiga(o). Cerca de $35,1 \%$ dos inquiridos admite nunca ter mudado as configurações de privacidade das redes sociais online em que participa. 


\section{6 - Riscos e violência online}

Na penúltima secção foram abordadas as experiências dos inquiridos, vividas na primeira pessoa ou por alguém da sua rede social de contactos, no que diz respeito a comportamentos e condutas que se podem catalogar como de risco nas diversas plataformas digitais.

\section{Figura 22 - Conhece alguém que sofreu violência e coação nas redes sociais}

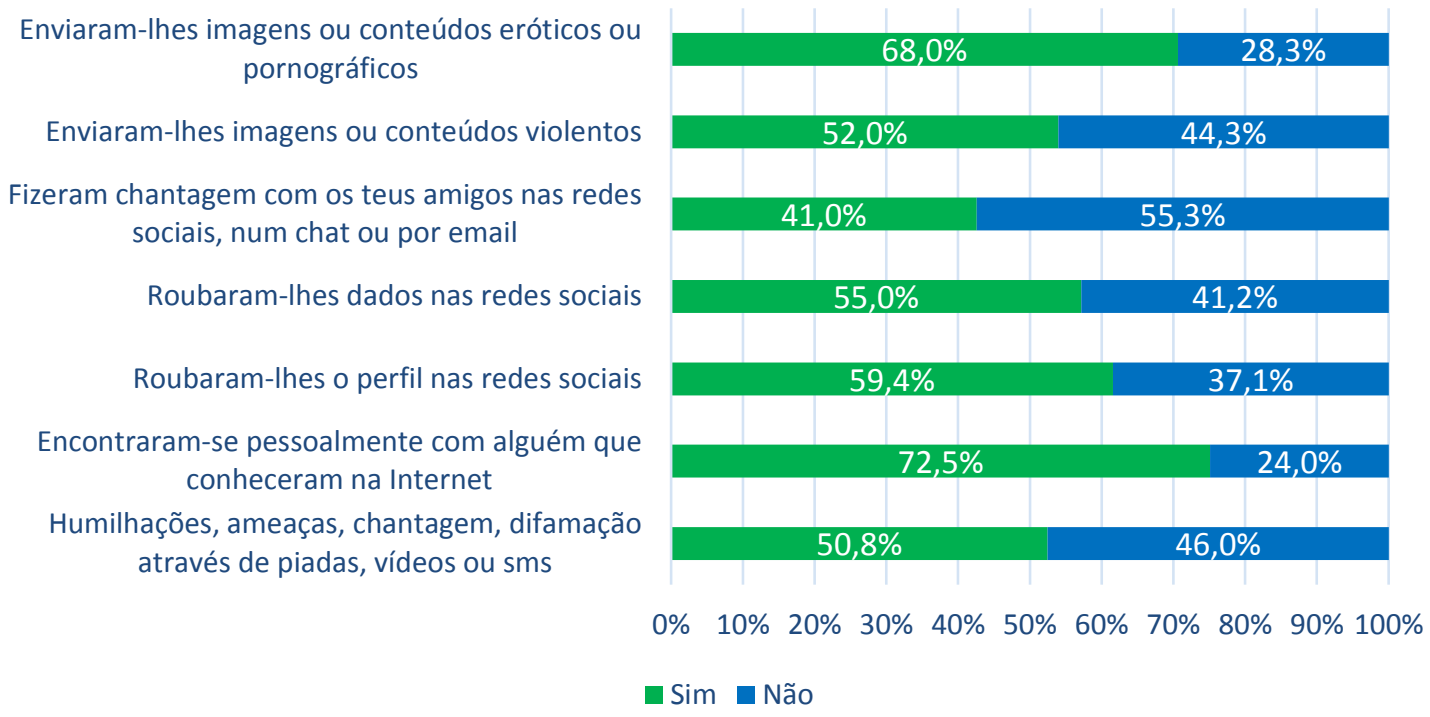

Fonte: Elaboração própria (resposta múltipla). Não incluí "não respostas”.

Em termos gerais, dever-se-á sublinhar que seis das sete preposições têm uma maioria afirmativa no sentido de conhecer alguém que já tenha vivenciado alguma destas situações (cf. Figura 22). Deste modo, aquela que se configura como mais recorrente $(72,5 \%)$ diz respeito a categoria de "encontraram-se pessoalmente com alguém que conheceram na internet". Nesta senda, são $68 \%$ aqueles que dizem conhecer alguém que já recebeu conteúdos eróticos ou pornográficos via internet. Há ainda a mencionar o roubo do perfil nalguma rede social online em $59,4 \%$ dos casos. A única situação que não ascende a uma maioria é a realização de chantagem via chat ou outro dispositivo online ao cifrar-se nos $41 \%$. 


\section{Figura 23 - Já experienciou as seguintes situações nas redes sociais}

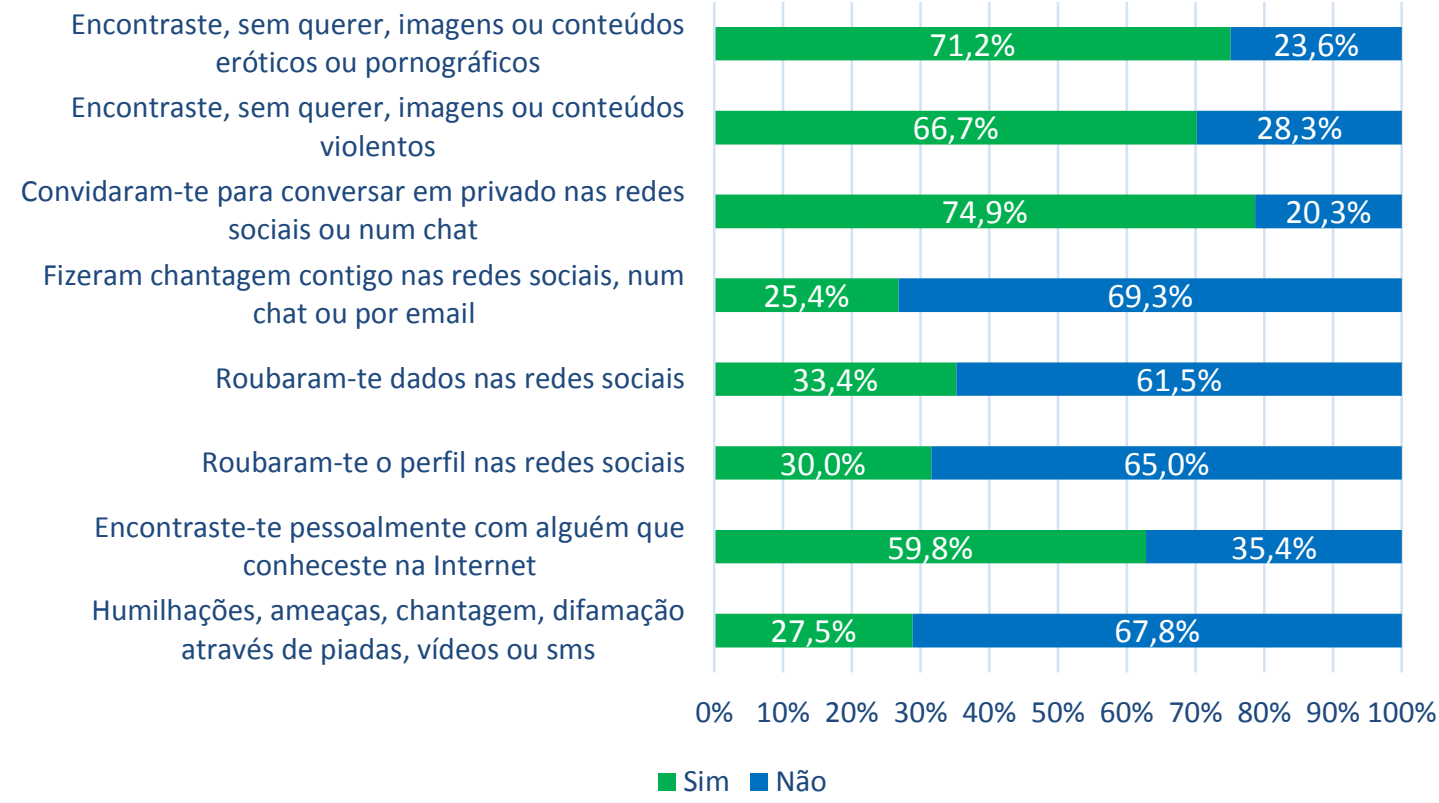

Fonte: Elaboração própria (resposta múltipla). Não incluí "não respostas".

A segunda bateria de questões era similar à anterior, contudo focava a experiência pessoal do inquirido (cf. Figura 23). Interessante que em geral os registos afirmativos são inferiores à questão anterior, particularmente na questão relativa às humilhações, ameaças e chantagem $(27,5 \%)$, mas o registo mais baixo diz respeito à chantagem nas redes sociais online, num chat ou por email com $25,4 \%$. Num segundo patamar de frequência, observamos o roubo do perfil nas redes sociais online e o roubo de dados nas redes sociais online com respetivamente $30 \%$ e 33,4\%. O grupo de quatro situações de maior frequência apresenta registos a rondar pelo menos 2/3: encontrar-se pessoalmente com alguém que conheceu na internet com 59,8\%, encontrar conteúdos violentos com $66,7 \%$, encontrar conteúdos eróticos ou pornográficos com $71,2 \%$ e o convite para conversar em privado numa rede social online ou chat com $74,9 \%$. Em termos gerais, os inquiridos indiciam ter maior facilidade em identificar situações de risco que envolvam outros atores, como amigos ou familiares, comparativamente às experiências vividas em primeira pessoa no espaço digital. 


\section{7 - Literacia digital}

A última secção aborda a literacia digital de forma genérica e apenas por intermédio de uma questão que tem na Figura 24 os dados empíricos recolhidos.

\section{Figura 24 - Quem deve informar e ensinar}

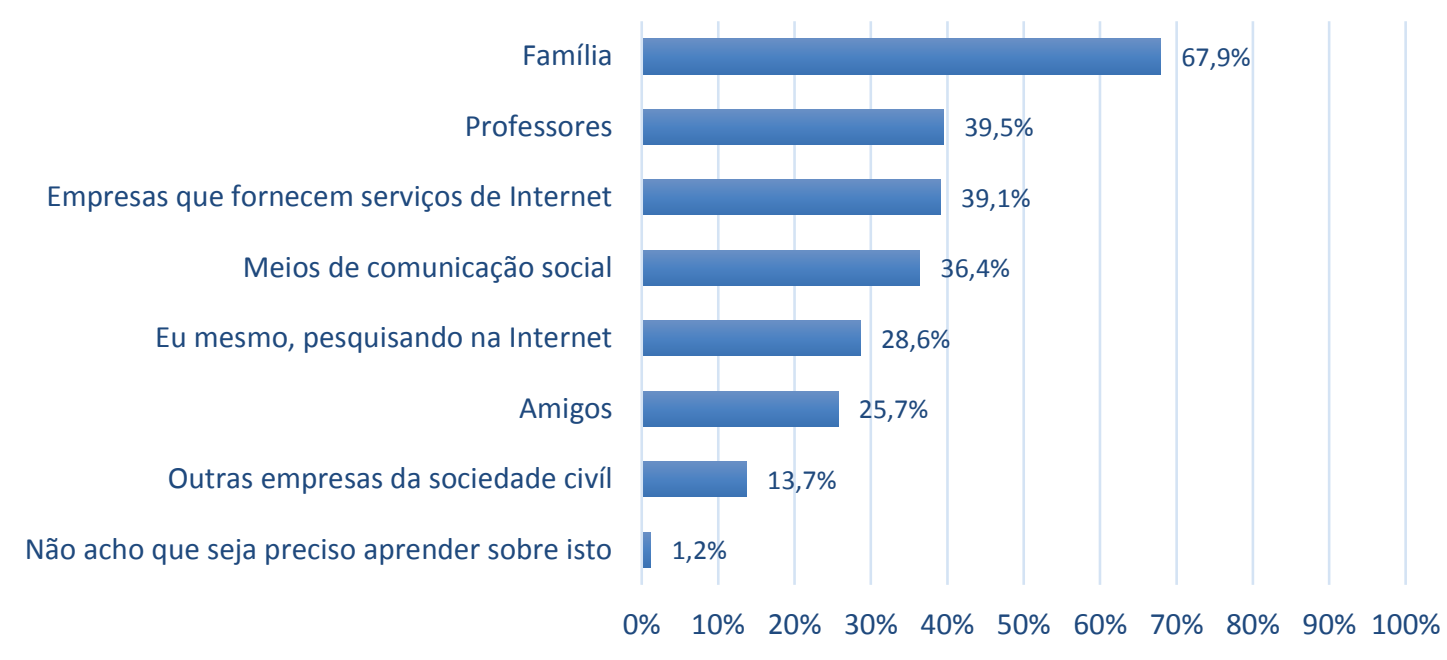

Fonte: Elaboração própria (resposta múltipla)

Da leitura da figura 24 resulta uma primeira evidência substantiva, os inquiridos esperam que a família seja o principal agente de socialização de literacia digital $(67,9 \%)$. De forma complementar, para $1 / 3$ dos inquiridos os professores (39,5\%), as empresas que fornecem serviços de internet $(39,1 \%)$ e os meios de comunicação $(36,4 \%)$ devem ser agentes privilegiados nesse processo de capacitação. As restantes opções afastam-se destes registos. Deste modo, e de acordo com os jovens inquiridos angolanos cabe à família a transmissão de competências de literacia dos media que permitam potenciar os conhecimentos/ capacidades/habilidades e atenuar os riscos dos atores em contexto online. 


\section{3 - Nota Metodológica}

A operacionalização da pesquisa empírica foi perspetivada desde uma estratégia metodológica quantitativa-extensiva, tendo por base o inquérito por questionário.

Este instrumento metodológico foi desenvolvido por um grupo de investigadores do Departamento de Ciências da Comunicação da Universidade Autónoma de Lisboa, a partir do cruzamento de diversas fontes de informação. As mais importantes foram o inquérito europeu EU Kids Online e diversos estudos da responsabilidade do britânico Office of Communications (Ofcom), do português Observatório da Comunicação (OberCom) e da ONG brasileira SaferNet. Na sua versão final, o questionário continha 27 questões, agrupadas nos seguintes blocos temáticos:

- Dados sociodemográficos e de contexto familiar;

- Práticas digitais;

- $\quad$ Riscos e vulnerabilidades no mundo digital.

O inquérito por questionário foi aplicado a uma amostra representativa de 1890 alunos que frequentavam os 1 - e 2 - Ciclos de Ensino de Angola, distribuídos por quatro escola da cidade de Lubango. Duas das escolas são do Ensino Público e outras duas do Ensino Privado. Foram validados 1715 , tendo como critério o preenchimento do Inquérito até à questão relativa à frequência de práticas online (metade do inquérito).

O questionário foi preenchido via plataforma online, por cada um dos inquiridos em contexto de aula. Os questionários foram de autopreenchimento (em situação de dúvida, os inquiridores estavam disponíveis para ajudar) no software KoBoCollet que foi instalado em 15 dispositivos portáteis. Constituindo-se como uma amostragem não probabilística por conveniência.

A recolha dos dados decorreu entre os meses de outubro e novembro de 2019. O trabalho de campo foi da responsabilidade do coordenador do estudo em Angola, Hélder Bahu. 0 tratamento de dados foi realizado em SPSS - Versão 25. 


\section{4 - Ficha Técnica}

\begin{tabular}{|c|c|}
\hline Título & $\begin{array}{l}\text { Práticas, consumos e riscos digitais dos jovens estudantes } \\
\qquad \text { Angolanos }\end{array}$ \\
\hline $\begin{array}{c}\text { Data da realização do } \\
\text { estudo }\end{array}$ & 2019 \\
\hline Coordenação & Hélder Bau, Bruno Reis e Paula Lopes \\
\hline Investigadores & $\begin{array}{c}\text { Bruno Reis, Carlos Pedro Dias, Hélder Bahu, João Carlos } \\
\text { Sousa, Paula Lopes e Vitor Tomé }\end{array}$ \\
\hline Assistentes de investigação & $\begin{array}{l}\text { Helder Bahu, António Chisingui, José Alexandre, João } \\
\text { Hequer, Domingos Manuel, Abel Bala, Hervé Vela, Marina } \\
\text { Rafael, Eva Lombe, Armindo Gabriel, Belindo Alberto, José } \\
\text { Kangombe, Paulo Handa, Neusa Arnaldo, Vitorino Isaul, } \\
\text { Nelson Tchanja, Miguel Tchimo, Associação de estudantes } \\
\text { do Instituto Médio de Economia do Lubango (IMELUB), } \\
\text { Direcção do Colégio 123, Direcção do Colégio O Pirilampo } \\
\text { Associação de estudantes do ISCED - Instituto Superior de } \\
\text { Ciências da Educação - Huíla }\end{array}$ \\
\hline Financiamento & $\begin{array}{l}\text { Instituto Superior de Ciências da Educação - Huíla } \\
\qquad \text { (ISCED) } \\
\text { Universidade Autónoma de Lisboa (UAL) }\end{array}$ \\
\hline
\end{tabular}

Estudo realizado em 2019

ISBN 978-989-9002-09-8

DOI https://doi.org/10.26619/978-989-9002-09-8

Universidade Autónoma Editora 